\title{
Geochemical identity of pre-Dogon and Dogon populations at Bandiagara (Mali, 11th-20th cent. AD)
}

\author{
A.-F. Maurer ${ }^{\mathrm{a}, \mathrm{b}, *}$, A. Person ${ }^{\mathrm{a}}$, A. Zazzo ${ }^{c}$, M. Sebilo ${ }^{\mathrm{d}}$, V. Balter ${ }^{\mathrm{e}}$, F. Le Cornec ${ }^{\mathrm{f}}$, V. Zeitoun ${ }^{g}$, \\ E. Dufour ${ }^{\mathrm{c}}$, A. Schmidt ${ }^{\mathrm{h}}$, M. de Rafélis ${ }^{\mathrm{i}}$, L. Ségalen ${ }^{\mathrm{a}}$, R. Bedaux ${ }^{\mathrm{h}}$ \\ a Laboratoire Biominéralisations et Environnements Sédimentaires, Sorbonne Universités, UPMC-Paris 06, UMR CNRS 7193, ISTeP, F-75005 Paris, France \\ b Laboratorio HERCULES, Universidade de Evora, Palacio do Vimioso, Largo Marques de Marialva, 8, 7000-809 Evora, Portugal \\ " Unité Mixte de Recherche 7209 "Archéozoologie, Archéobotanique: Sociétés, Pratiques et Environnements", Centre National de la Recherche Scientifique, Muséum \\ National d'Histoire Naturelle, Sorbonne Universités, CP 56, 55 rue Buffon, F-75005 Paris, France \\ d Sorbonne Universités, UPMC Univ Paris 06, CNRS, Institute of Ecology and Environmental Sciences (IEES), 4 Place Jussieu, 75005 Paris, France. \\ e Laboratoire de Géologie de Lyon, UMR 5276, CNRS/Ecole Normale Supérieure de Lyon/Université Lyon 1, 46 Allée d'Italie, 69364 Lyon Cedex 7, France \\ ${ }^{\mathrm{f}}$ IRD LOCEAN (UMR 7159), IPSL/IRD/UPMC/CNRS/MNHN IRD France Nord, 32 avenue Henri Varagnat, 93143 Bondy Cedex, France \\ ${ }^{g}$ UMR 7207-CR2P-Cnrs-Mnhn-Université Paris 6, Sorbonne Universités, Université Pierre et Marie Curie, T. 46-56, 5ème Étage, Case 104, 4, Place Jussieu, 75 252 Paris \\ Cedex 05, France \\ h National Museum of Ethnology, Steenstraat 1, Leiden, The Netherlands \\ ${ }^{i}$ Géosciences Environnement Toulouse (GET), Univ. Paul Sabatier, UMR CNRS 5563, 31400 Toulouse, France
}

\section{A R T I C L E I N F O}

\section{Keywords:}

Trace elements

Stable isotopes

Bones

Dogon

Diet

Mobility

\begin{abstract}
A B S T R A C T
Bone geochemistry of pre-Dogon (11th-16th cent. AD) and Dogon (17th-20th cent. AD) populations buried in two caves of the Bandiagara Cliff (Mali) was examined for the purpose of exploring their diet and mobility. While the Dogon were the subject of extensive ethnographic studies, the lifestyle of the pre-Dogon, so-called "Tellem" is not known. We therefore compared the geochemical composition of Dogon bones with the results obtained from modern dietary surveys in Mali, to establish the parameters of a dietary model that was further applied to the pre-Dogon in order to expand our knowledge concerning their way of life.

The exceptional preservation of the bones of both populations was confirmed not only at the macroscopic scale, but also at the mineralogical, histological and geochemical levels, which resemble those of fresh bones, and therefore offered ideal conditions for testing this approach.

The application of the Bayesian mixing model FRUITS, based on bone $\delta^{13} \mathrm{C}$ (apatite and collagen) and bone $\delta^{15} \mathrm{~N}$ values, suggested a dietary continuity through time, from the 11 th century to today. Bone barium (Ba) content revealed very restricted mobility within the Cliff while bone $\delta^{18} \mathrm{O}$ values indicated that Pre-Dogon and Dogon most likely occupied the Bandiagara Plateau and the Cliff, respectively.
\end{abstract}

\section{Introduction}

Almost a century has passed since the Dakar-Djibouti mission lead by Marcel Griaule (1932), who shed light on the inhabitants of the Bandiagara Cliff, the Dogon population. Encountered by Louis Desplagnes in 1905 and first called the Habé, the Dogon are particularly known for the complexity and richness of their culture, expressed through their architecture, masks, rituals and beliefs (Bedaux and Van der Waals, 2004). Many other expeditions have been conducted, but the Dakar-Djibouti mission was the first to conduct intensive ethnological, anthropological, zoological and entomological surveys and collection in West and Equatorial Africa. Although this work has long been a reference for French Africanist anthropology, the overemphasized spiritual dimension of the Dogon society conveyed by Griaule and colleagues has been since criticized (Doquet, 2005; van Beek, 1991).

Based on the work conducted by Desplagnes, Griaule and later Dieterlen (Desplagnes, 1907; Dieterlen, 1941; Griaule, 1932, 1938; Griaule and Dieterlen, 1965), a Dutch architect, Haan, followed by an inter-disciplinary team led by Huizinga, who involved human biologists, archaeologists, anthropologists and geneticists, led expeditions from 1964 to 1971 to visit the Bandiagara Cliff, and more specifically the region of Sanga. They discovered and excavated several caves whose material culture and remains were attributed to three populations, namely the Toloy, Tellem and Dogon (Bedaux, 1972, 1988). Besides providing the first radiocarbon dates on human bones and charcoal in that area, the research showed a genetic discontinuity

\footnotetext{
* Corresponding author at: Laboratoire Biominéralisations et Environnements Sédimentaires, Sorbonne Universités, UPMC-Paris 06, UMR CNRS 7193, ISTeP, F-75005 Paris, France.

E-mail addresses: annefrance.maurer@gmail.com, amaurer@uevora.pt (A.-F. Maurer).
} 
between the Tellem and the Dogon, as well as changes in material culture around the 15th cent. AD (Bedaux, 1972).

More recently, a Swiss team led by Huysecom and conducting interdisciplinary studies (archaeology, ethnology, archaeobotany, geomorphology) since 1997 in the Dogon Country, has argued for a continuous occupation of the region for the past 4000 years (Mayor et al., 2005, 2014; Ozainne, 2013). They also made the assumption that coiled-clay structures in cave A, dated from the 5th cent. BC to the 2nd cent. AD, and identified as granaries 40 years ago (Bedaux, 1972) were constructed as burial places. Similar structures at Douro-Boro were dated from the 5th to 6th cent. AD (Mayor et al., 2014), and yielded skeletons from the 7th to 9th cent. $\mathrm{AD}$, hence they were slightly older than the collective sepulchral caves used by the Tellem (11th-16th cent. AD, Bedaux, 1972). These new data led Mayor et al. (2014) to prefer the term "pre-Dogon population" over the classic division Toloy-Tellem, to better characterise a chrono-cultural continuity. In addition, they also stress the fact that these pre-Dogon populations should not be seen as isolated but rather interacted with a wide social network, according to the presence of glass beads whose geochemical composition indicated a provenance from Asia (Mayor et al., 2014).

In this paper, we investigate pre-Dogon and Dogon diets using bone geochemistry to see whether cultural continuity in terms of dietary practices can be observed through time from the 11th cent. AD to today, and to decipher potential interactions with populations from the adjacent West African empires explored via the degree of mobility of these populations.

Archaeological bone geochemistry has been increasingly used for approximately the last 30 years to study dietary habits and movements of past populations. Dietary behavior and mobility patterns are archived in the skeleton during an individuals' life, through the ingestion of dietary components whose specific chemical composition depends on their nature and location. For example, the consumption of $\mathrm{C}_{3} / \mathrm{C}_{4}$ plants, whose isotopic composition varies with different photosynthetic pathways (Ehleringer, 1989; O'Leary, 1981), is inferred from bone carbon isotopic values recorded in bone apatite and/or bone collagen (DeNiro and Epstein, 1978). The investigation of water supply, the isotopic composition of which depends on environmental factors (latitude, altitude, distance to the coast, Dansgaard, 1964) is deduced from oxygen isotope ratios recorded in bone apatite (Longinelli, 1984). Additionally, the trophic level position is provided by $\mathrm{Sr} / \mathrm{Ca}$ and $\mathrm{Ba} / \mathrm{Ca}$ ratios registered in bone apatite (Balter et al., 2001, 2002, 2012; Burton et al., 1999; Elias et al., 1982), as well as, nitrogen isotope ratios of bone collagen (DeNiro and Epstein, 1981). Together, these common proxies, based on the fact that "we are what we eat and drink", offer insight into the structure and organisation of past societies (Loftus et al., 2016; White, 2005).

Pre-Dogon and Dogon individuals constitute an extraordinary population for using this approach. Indeed, protected from humidity and temperature variation in sepulchral caves, the macroscopic preservation of these individuals is exceptional and clearly contrasts with that of archaeological bones from arid contexts. Additionally, archaeologists and ethnologists extensively studied the system of thought and way of life of the Dogon people for $>100$ years (Bedaux, 1972, 1986; Desplagnes, 1907; Dieterlen, 1941; Gallay et al., 1995; Griaule, 1932, 1938; Griaule and Dieterlen, 1965; Huysecom, 2002), while in contrast little is known about the pre-Dogon (Bedaux, 1972). They were occupying the Bandiagara Cliff before the arrival of the Dogon but their provenance, genetic affiliation, way of life, as well as settlement location continue to be investigated (Bedaux, 1972). Finally this work will also expand the anthropobiogeochemical database of West Africa that may constitute a robust baseline for further dietary reconstructions (Balter, 2001; Maurer et al., 2014; Person et al., 2012; Zeitoun et al., 2005).

\section{The Dogon country: setting}

The Dogon country is located to the east of the inner Niger Delta, near to Bandiagara in the center of the Republic of Mali, in the SudanoSahelian zone (Fig. 1). The vegetation cover consists of bushes and

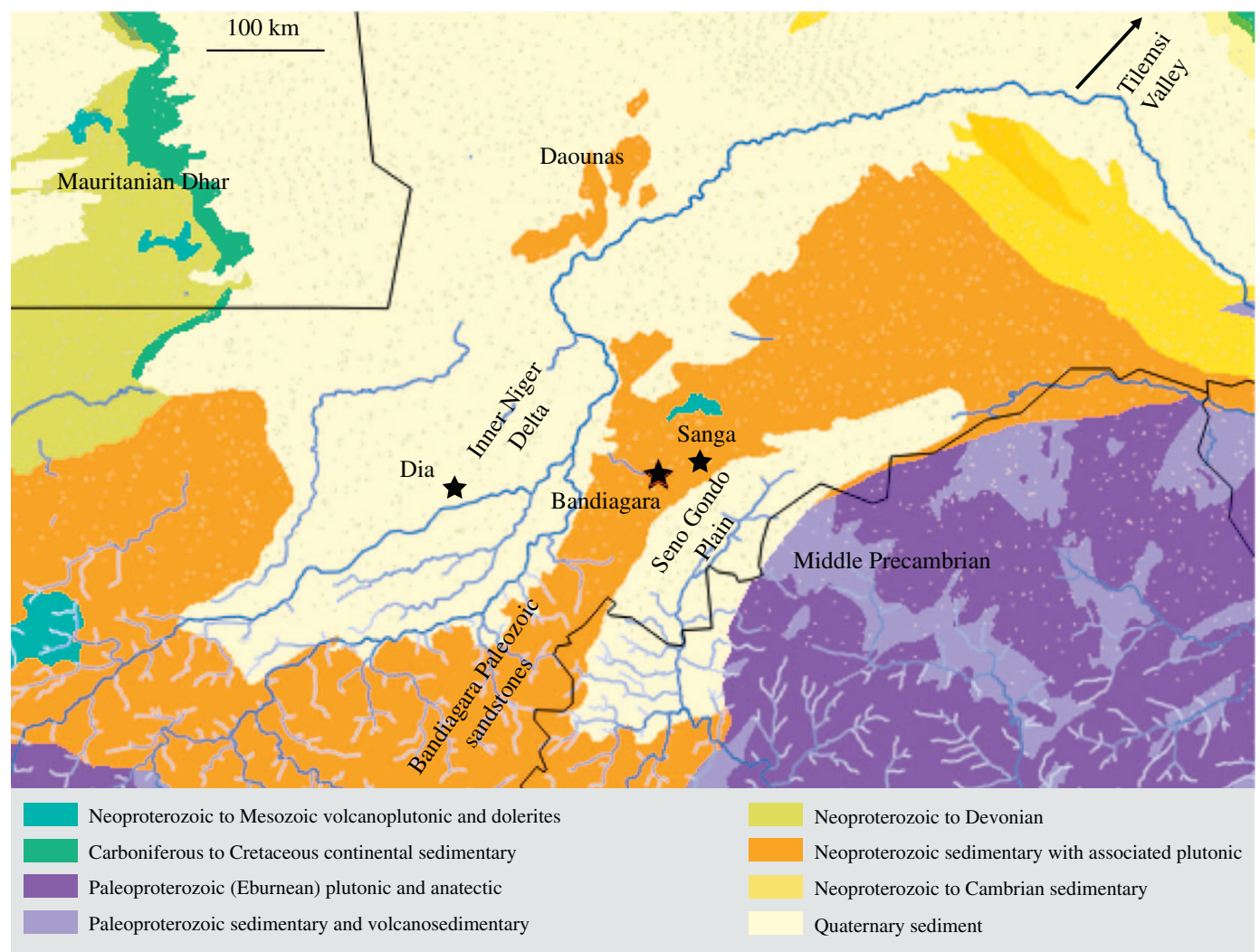

Fig. 1. Location of the study area. The WFS layer from server "http://mapsref.brgm.fr/wxs/1GG/SIGAfrique_BRGM_Africa_Geology" was used for the geological map. 


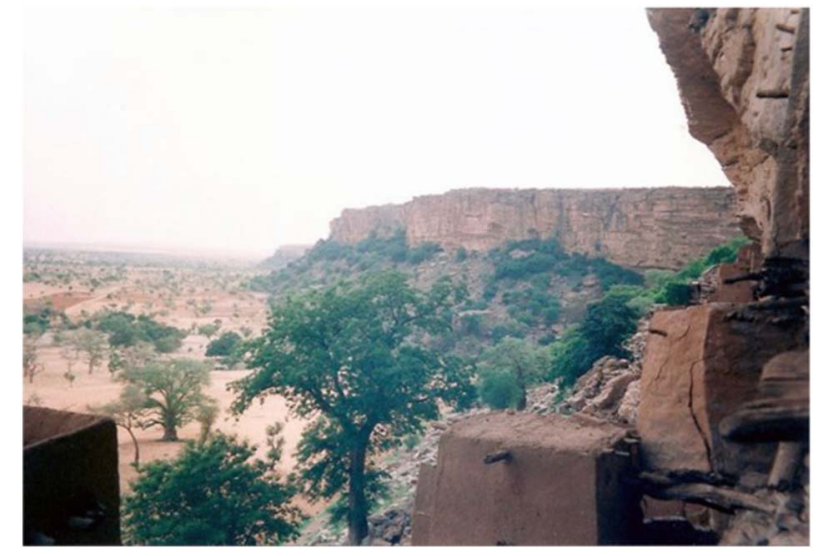

Fig. 2. Photograph showing the Bandiagara Plateau, the Bandiagara Cliff and the Plain of Seno-Gondo. https://fr.wikipedia.org/wiki/Fichier:Falaise_de_Bandiagara2.jpg\#file

shrub savannah, which are characteristics of Sahelian climate (Mayor et al., 2005), with three yearly seasons: warm and dry from February to June, warm and humid from June to October and dry and cold from November to February (Palau Marti, 1957). Temperature is around 28/ $29^{\circ} \mathrm{C}$ at Bandiagara (Mayor et al., 2005) and rainfall varies from $350 \mathrm{~mm} \cdot \mathrm{yr}^{-1}$ in the north, to $500 \mathrm{~mm} \cdot \mathrm{yr}^{-1}$ in the south of the Dogon country, with a mean evaporation flow of around $1700-1900 \mathrm{~mm} \cdot \mathrm{yr}^{-1}$ (Banga, 2004). Precipitation yields are higher around the Cliff due to orogenic effects (Bedaux, 1972).

Three geomorphological features characterise the Dogon country: the Bandiagara Plateau, the Bandiagara Cliff and the Plain of SenoGondo (Fig. 2). The escarpment runs from NE to SW for about $260 \mathrm{~km}$, rising from $100 \mathrm{~m}$ in the SW to $700 \mathrm{~m}$ in the NE on the plain of Gondo (Banga, 2004). The Bandiagara Cliff delimits a plateau composed of Cambro-Ordovician sandstones and quartzites (Fig. 1). The Plateau is crossed by faults, which grew with erosion, to form caves in the sandstones (Bedaux, 1972). This karst-like system combined with the schist layer, on which the Plain of Seno-Gondo stretches for about $100 \mathrm{~km}$ towards the east of the Cliff (Daveau, 1959), provides water sources and ponds located at the base of the Cliff. The availability of water resources and the presence of more fertile lands along the escarpment than those found in the Plain (Gallais, 1965) offer favourable conditions for the populations to settle in an arid environment (Brasseur and Le Moal, 1963).

The history and origin of the Dogon remain unclear (Bedaux, 1972). According to the inter-disciplinary study of Mayor et al. (2005), the dynamic of the populations is highly complex and governed by climate instability and economic and religious pressures coming from the successive neighbouring medieval empires of Ghana, Dia, Mali and Mossi from the 8 th to the 19th cent. AD. Briefly, the Plateau was occupied during more humid periods whereas the Cliff played the role of a refuge zone, offering permanent water resources, similarly to what can be found in the Mauritanian Dhar (Person et al., 2012).

The occupation of the Dogon country can be summarised as follows (cf. Bedaux, 1972 and Mayor et al., 2005, Fig. 12 p: 50): during the dry period which affects the Sahara from 10th cent. BC to 3th/4th cent. AD, human occupation was restricted to the Cliff from the 5th cent. BC onwards. This was followed by a more humid phase (between 7th and 11th cent. AD) when the pre-Dogon populations started to settle onto the Plateau, which provided sufficient natural resources. Meanwhile, the Cliff seems to have been abandoned by the populations until they made use of the caves for collective burials and religious purpose. Four dates obtained from human bones buried in cave $\mathrm{C}$ and $\mathrm{B} 1$, situate these practices between the 11th and 15th cent. AD (Bedaux, 1972). The location of these pre-Dogon settlements is not known. However, harsh conditions, related to the progressive aridification and conflicts with the adjacent Empires, must have prevailed on the Plateau. These pre-

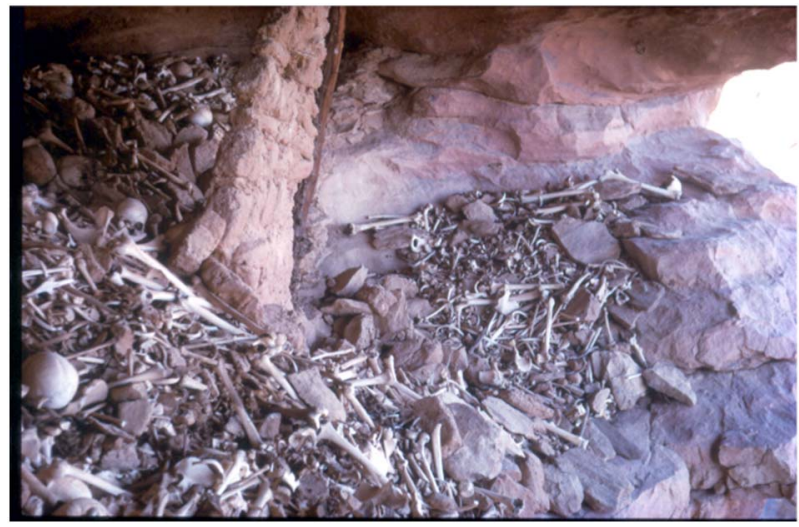

Fig. 3. Photograph of the skeletons buried in cave C. Courtesy of the National Museum of Ethnology, Leiden; photo G. Jansen.

Dogon would have shared the Cliff with the first Dogon, chased from the Plain by the Mossi, whose arrival in two successive waves in the 13th and the 15th is evidenced by changes in the functional use of the caves, followed later by changes in material culture and architecture (Bedaux, 2004).

While only a few caves were excavated and dated, anthropometric studies have revealed genetic differences between pre-Dogon and Dogon (Huizinga, 1968) although they may have been in contact (Bedaux, 1972; Griaule and Dieterlen, 1965). The origin and disappearance of these pre-Dogon populations are still under debate (Bedaux, 1972).

The human skeletons analysed in this study come from two caves of the Bandiagara Cliff that were used for collective burials (Fig. 3): Cave $\mathrm{C}$ and Cave $\mathrm{H}$. The caves are separated by a hundred meters, and located in the wall of a corridor that was created by erosion and runs in parallel to the Cliff, near to Sanga (Fig. 1). Human remains of Cave C have been attributed to pre-Dogon and dated from the 11th to the 15th cent. AD (Bedaux, 1972). In Cave H, human remains were probably Dogon, according to the local population (Bedaux, 1972).

The skeletons of Cave C were excavated in 1965, 1966 and 1971 and those of Cave $\mathrm{H}$ in 1971, behind a wall constructed in sun dried mudbricks. The skeletons were lying on the ground in a highly disordered way. However, the macroscopic state of preservation of the bone tissues was excellent as assessed by remains of ligaments still adhering to the bones. The oldest Cave C (pre-Dogon) was the biggest sepulchral cave examined in 1971. It contained between 2500 and 3500 individuals buried in around $81 \mathrm{~m}^{3}$, mostly adults, males and females, and $12 \%$ of non-adults (Bedaux, 1972). Children under 5 years old were not buried in the cave. The skeletons were tidied up in order to create some space for the new dead (Bedaux, 1972), a ritual habit still in use by the Dogon (Desplagnes, 1907). Therefore, none of the skeletons were found in their original anatomic position. The dead were dressed before burial as suggested by the high amount of textile remains (cotton, tunics, trousers, loincloths, coifs). Other remains consist of wooden objects (headrests, flute, bows, arrows, knife handle) as well as vegetation remains (rope, basket, bark, calabash, stem fragment of millet), and leather, ceramic and iron objects (bracelet, rings, pins). A few skulls of domesticated (cattle, sheep) and wild (antelope, buffalo and gazelle) animals were also accompanying the dead. In contrast to Cave $\mathrm{C}$, the more recent Cave $\mathrm{H}$ provided only 24 individuals, mostly females. The pell-mell disposition of the skeletons was caused by monkeys, whose presence was assessed by faecal remains (Bedaux, 1972). Only textile, different from that found in Cave $\mathrm{C}$, and two dog mandibles were found with the human skeletons.

\section{Material}

In order to avoid intra-individual sampling, the geochemical 
analyses were performed on 12 left femora from Cave C and 10 right femora from Cave $\mathrm{H}$. One right femur from Cave $\mathrm{C}$ was also analysed as it was used for radiocarbon dating. In order to establish an environmental geochemical baseline for further comparison with the geochemical data obtained from the human bones, archaeological fauna and flora were also sampled: one stem fragment of millet from Cave $\mathrm{P}$ (pre-Dogon, dated from the 12th to 15th cent. AD, GX-0233, Bedaux, 1972) and five skull bone samples of pre-Dogon Bos sp. (3 from Cave C and two from Cave P). Archaeological samples were provided by the National Museum of Ethnology at Leiden, the Netherlands. Modern mandibles from herbivores (one sheep/goat and one cow) as well as modern crops (pearl millet, sorghum and rice) from the surroundings of Dia (Fig. 1) were also analysed to provide a geochemical baseline for the Inner Niger Delta, a neighbouring geo-ecosystem. These samples were collected in 2000 by V. Balter. Finally, two additional samples of millet flour and fonio from Mali and bought in a French grocery were added to the plant samples.

\section{Method}

Bone analyses were carried out on the cortical part of midshaft femora collected at the National Museum of Ethnology in Leiden, the Netherlands. The samples were cut off using a drill equipped with diamond disc and the bone surfaces were mechanically cleaned using a diamond burr.

\subsection{Histological analysis}

A polyester resin was used to embed transverse bone sections under vacuum. When dried, the bone sections were cut with a diamond saw and glued on glass slides. Cerium oxide was used to polish the thin sections to a final thickness of $\sim 30 \mu \mathrm{m}$ (Maurer et al., 2011). Bone histological features modified post-mortem, such as alteration of the Haversian system (Hedges et al., 1995), presence vs. absence of microbacterial attack (Child, 1995; Collins et al., 2002; Jans et al., 2004) and of microcracking (Piepenbrink and Schutkowski, 1987; Pfretzschner and Tütken, 2011), were examined via optical transmitted light microscopy. Authigenic precipitations in bone porosity, as well as collagen birefringence were assessed through cross polarised light (Fig. 4).

\subsection{Crystallinity analysis}

Bone powder, obtained using an agate mortar and pestle, was pressed in a glass-aluminium sample-holder. X-ray diffraction analysis (XRD) was performed using a Siemens D500 diffractometer with Nifiltered $\mathrm{CuKa}$ radiation at $40 \mathrm{kV}$ and $30 \mathrm{~mA}$. Samples were scanned from $2^{\circ}$ to $70^{\circ}(2 \theta)$, with counting for $6 \mathrm{~s}$ every $0.02^{\circ}$, in a rotating sample-holder. Bone mineralogical transformations were explored based on the XRD diffractograms (Fig. 5). The presence of diagenetic minerals e.g. calcite, barite and quartz in bone porosity, commonly observed in desert environments (Maurer et al., 2014; Piepenbrink and Schutkowski, 1987) was also checked.

\subsection{Chemical analysis}

\subsubsection{Trace elements}

Before being analysed for trace elemental content, bones are often exposed to pre-treatments involving various reagents, such as washing with $\mathrm{HNO}_{3}, \mathrm{H}_{2} \mathrm{O}_{2}$, acetone or formic acid (Degryse et al., 2004; Lösch et al., 2014; Shafer et al., 2008; Stipisic et al., 2014) although in some cases no pre-treatment is applied (Arnay-de-la-Rosa et al., 2009; Mays, 2003; Rasmussen et al., 2013; Skytte and Rasmussen, 2013). For skeletons buried in arid environments, a treatment with dilute acetic acid removes the secondary carbonates (Maurer et al., 2014; Sponheimer et al., 2005) that commonly precipitate in the porosity of the archaeological bones and teeth (Pate et al., 1989; Piepenbrink and Schutkowski, 1987) and may bias their biological composition. Acetic acid is also routinely used for pre-treating bones and teeth before strontium isotope analysis (Alt et al., 2014; Scheeres et al., 2013).

However, in this study, this step was avoided because firstly, carbonates are absent from the burial environment, which consists of caves preserved from water percolation and formed in a sandstone escarpment. The absence of diagenetic calcite in bone voids was assessed checking bone Ca/P (Table 1), histological thin sections (Fig. 4), as well as XRD diffractograms (Fig. 5). Secondly, bone pre-treatment with acetic acid removes ante-mortem $\mathrm{Mg}$ and $\mathrm{Na}$ adsorbed onto bone apatite crystals (Maurer, 2008) and therefore may bias bone in vivo elemental signatures that might be still yielded by archaeological bones preserved in ideal environmental conditions. No acetic acid pre-treatment of the bone samples was therefore applied before following the procedure given in detail in Maurer et al. (2011).

Briefly, bone organic matter (OM) was removed via a low temperature $\left(300{ }^{\circ} \mathrm{C} / 27 \mathrm{~h}\right)$ heat treatment, which provides an estimate of bone OM content using bone \% weight loss during ashing. Samples were then dissolved in Suprapur nitric acid (Merck). Bone Ca, Mn, Fe, and $\mathrm{Mg}$ content was measured with an inductively coupled plasma atomic emission spectrometer (ICP-AES, Liberty 200, Varian). Bone Zn, $\mathrm{Sr}, \mathrm{Y}, \mathrm{Ba}, \mathrm{La}, \mathrm{Ce}$ and $\mathrm{U}$ content was analysed using a quadrupole inductively coupled plasma mass spectrometer (ICP-MS, UltraMass, Varian). SRM 1400 bone ash was used for quality control and as a substrate for avoiding matrix effects, for standard calibration, prepared from mono-elemental Spex solutions, $1000 \mu \mathrm{g} / \mathrm{mL}$ certified stock. ICP analyses were conducted at the Institut de Recherche pour le Développement (Bondy, France). Bone $\mathrm{PO}_{4}$ and $\mathrm{Na}$ content were respectively measured by colorimetry and Atomic Absorption Spectrometry.

\subsubsection{Stable isotope ratios recorded in bone collagen}

Bone collagen extraction was preceded by a solvent pre-treatment step (chloroform/methanol 2:1, $24 \mathrm{~h}$ ) in order to remove the presence of potential lipids. The same pre-treatment was applied to the plant samples previously washed with deionised water (Arnay-de-la-Rosa et al., 2011). Modern millet and sorghum were also analysed, for comparison, without any solvent pre-treatment. Bone collagen extraction is described in detail in Salesse et al. (2014). The procedure follows that of Longin (1971) modified by DeNiro and Epstein (1981) and Bocherens et al. (1991). Briefly, bone was demineralised with $\mathrm{HCl} 1 \mathrm{M}$ for $20 \mathrm{~min}$, humic contaminants removed with $\mathrm{NaOH} 0.125 \mathrm{M}$ for $20 \mathrm{~h}$ and collagen gelatinised in $\mathrm{HCl} 0.01 \mathrm{M} 17 \mathrm{~h} / 100{ }^{\circ} \mathrm{C}$. The gelatine was filtered, freeze dried with liquid nitrogen and lyophilised for $48 \mathrm{~h}$. Samples preparation was conducted at the Muséum national d'Histoire naturelle, Paris.

Bone collagen and plant $\delta^{13} \mathrm{C}, \delta^{15} \mathrm{~N}, \% \mathrm{C}$ and $\% \mathrm{~N}$ were measured using an Elemental Analyzer (Flash 2000, Thermo) coupled to a Thermo Scientific Delta V plus. Analytical precision of $\% \mathrm{C}$ and $\% \mathrm{~N}$ was $0.1 \%$. Isotopic calibration and corrections were based on different reference materials: tyrosine $\left(\delta^{13} \mathrm{C}=-23.2 \% 0, \quad \delta^{15} \mathrm{~N}=9.98 \%\right.$, laboratory standard), IAEA- $\mathrm{N}_{1}\left(\delta^{15} \mathrm{~N}=0.4 \%\right)$, IAEA- $\mathrm{N}_{2}\left(\delta^{15} \mathrm{~N}=20.3 \%\right)$, IAEANO-3 $\left(\delta^{15} \mathrm{~N}=4.7 \%\right.$ ) and expressed relative to N2-AIR for nitrogen and VPDB for carbon. Analytical precision was $\pm 0.1 \%$ for $\delta^{13} \mathrm{C}$ and \pm $0.2 \%$ for $\delta^{15} \mathrm{~N}$.

\subsubsection{Stable isotope ratios recorded in bone apatite}

Around $30 \mathrm{mg}$ of bone powder was immersed in $\mathrm{NaOCl} 2-3 \%$ for $48 \mathrm{~h}$ with regular vortexing until the complete elimination of organic matter. They were rinsed 5 times by centrifugation with bidistilled water. Acetic acid $0.1 \mathrm{M}$ was added for $4 \mathrm{~h}$ to the samples $\left(0.1 \mathrm{ml} \cdot \mathrm{mg}^{-1}\right)$ which were then rinsed 5 times and dried at $50{ }^{\circ} \mathrm{C}$ overnight.

Bone $\delta^{13} \mathrm{C}$ and $\delta^{18} \mathrm{O}$ values were obtained following reaction under vacuum at $70{ }^{\circ} \mathrm{C}$ with $100 \% \mathrm{H}_{3} \mathrm{PO}_{4}$ using a Kiel IV device connected to a 



pre-Dogon, Tellem Bandiagara, Mali, $11^{\text {th }}-16^{\text {th }}$ cent. AD
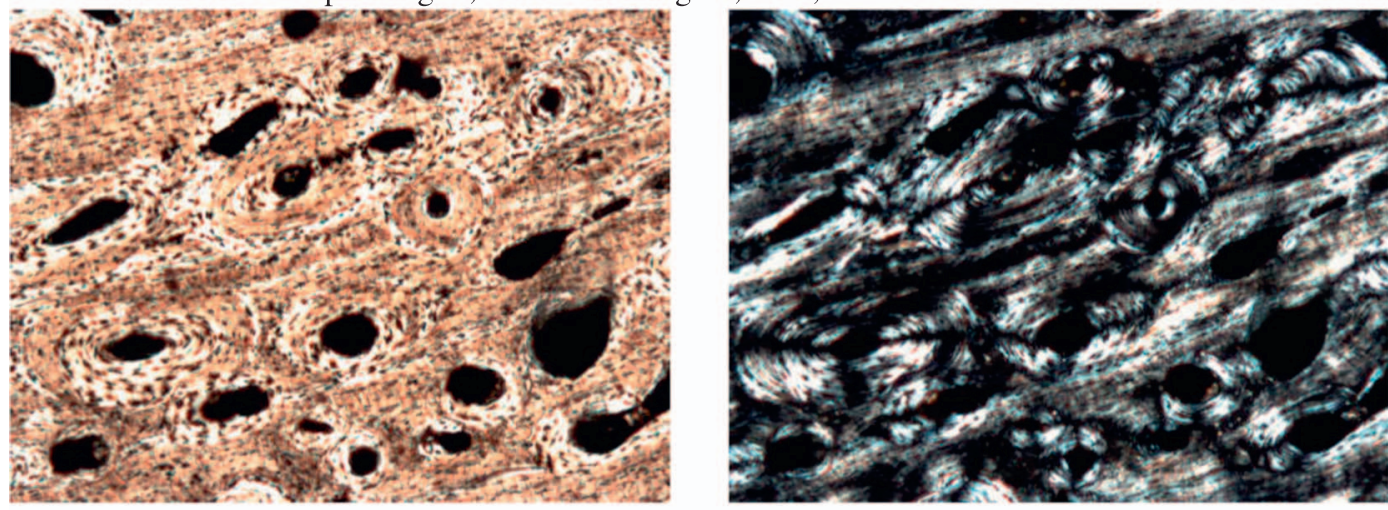

Dhar Nema, Mauritania, Neolithic
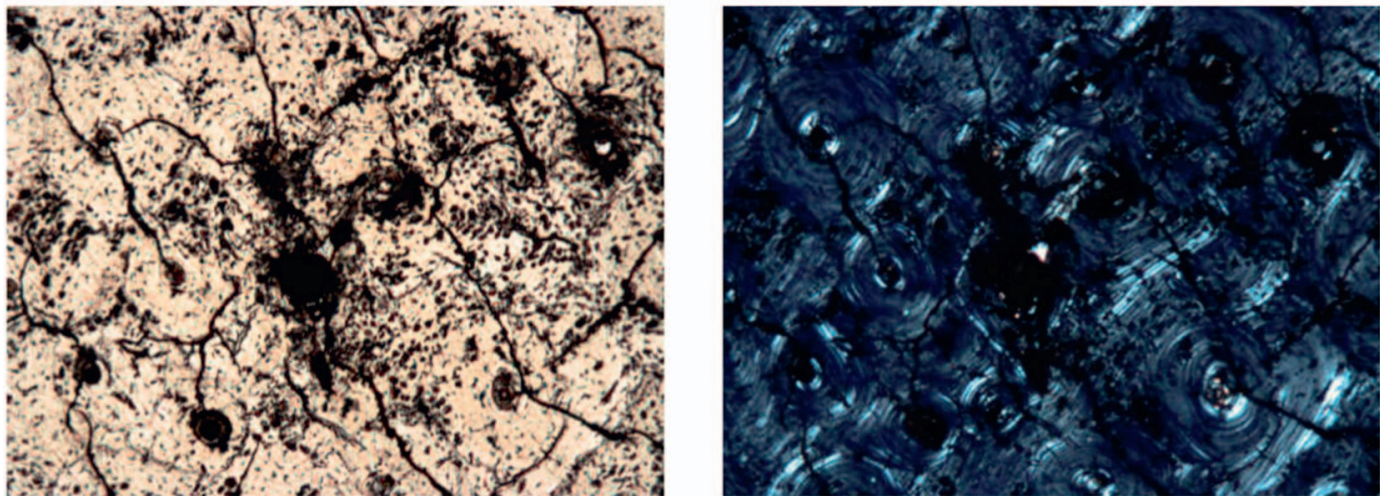

Daounas, Mali, Neolithic
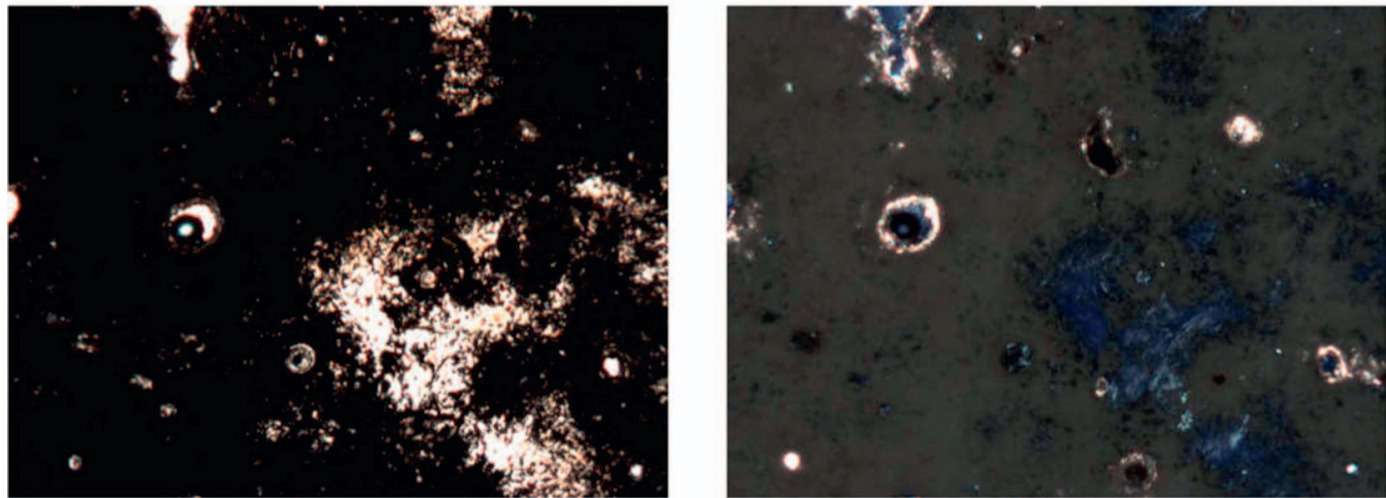

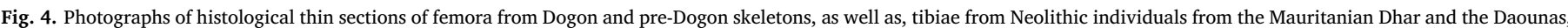
provided for comparison and previously published in Maurer et al. (2014).

Photographs were taken using optical transmitted light microscopy (left) and cross polarised light (right). 

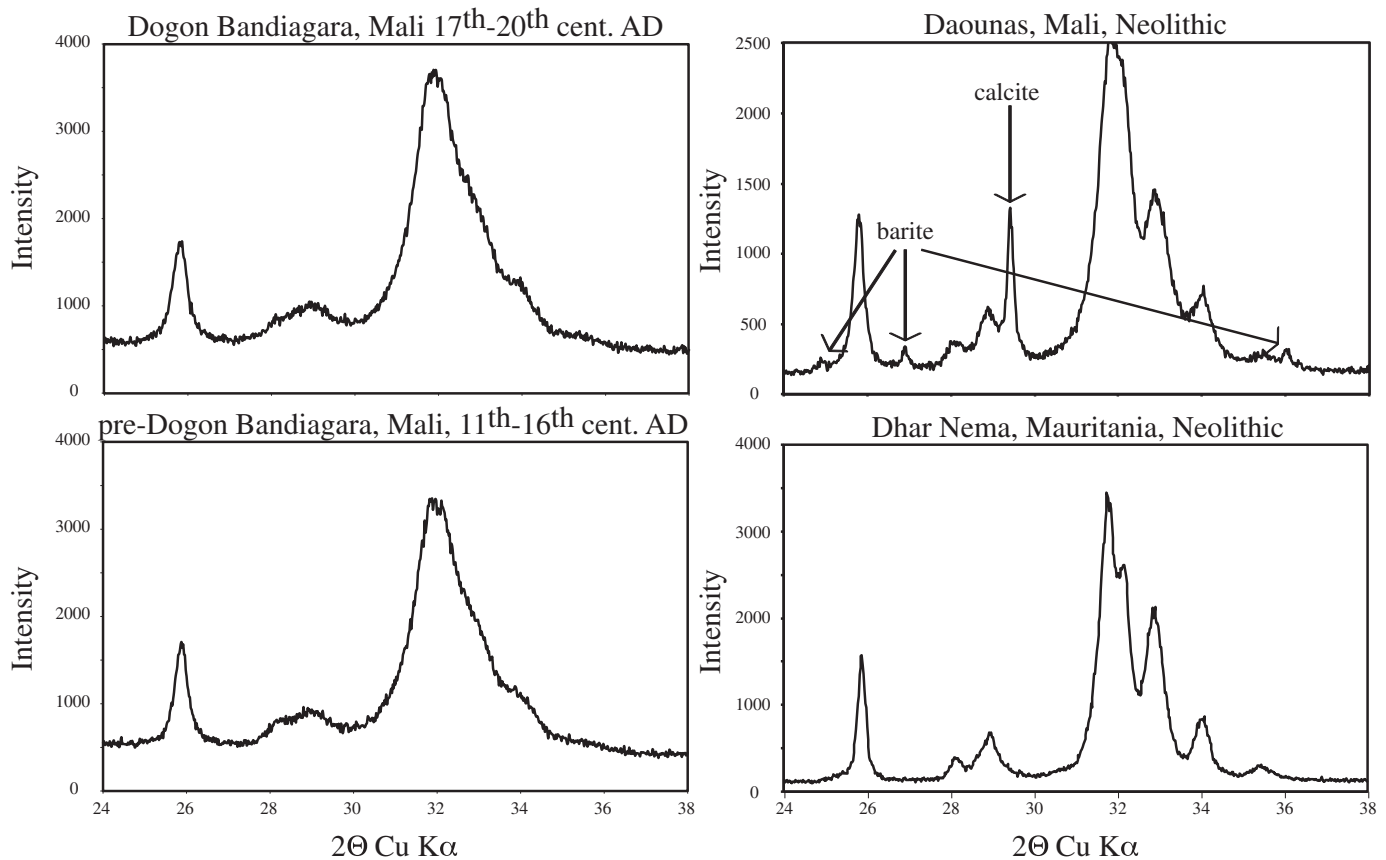

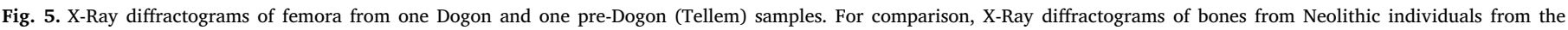
Mauritanian Dhar and the Daounas (Maurer et al., 2014), are also displayed.

Delta V Advantage mass spectrometer (Thermo Scientific) at the Laboratory Biominéralisations et Environnements Sédimentaires, University of Paris VI. Stable carbon and oxygen isotopic compositions are reported in per mil (\%) relative to V-PDB. Laboratory standards calibrated against NBS 19 gave a reproducibility of replicate analyses of $0.04 \%$ for $\delta^{13} \mathrm{C}$ and $0.08 \%$ for $\delta^{18} \mathrm{O}$.

\subsubsection{Radiocarbon dating}

Six bone collagen samples ( 5 human bones: 2 Dogon from Cave $\mathrm{H}$ and 3 pre-Dogon from Cave C; and 1 Bos sp. from Cave C) were prepared for AMS ${ }^{14} \mathrm{C}$ dating using the collagen previously extracted (cf. 4.3.2) and combusted for 25 to $83 \mathrm{~min}$ at $800{ }^{\circ} \mathrm{C}$. The $\mathrm{CO}_{2}$ released by the samples was trapped cryogenically and preserved in sealed tubes that were sent to the Artemis AMS laboratory in Saclay (France) for graphitization and ${ }^{14} \mathrm{C}$ measurement. The dates were calibrated using OxCal 4.2.4 and the IntCal09 calibration curve (Bronk Ramsey and Lee, 2013; Reimer et al., 2009). Calibrated intervals are given at $2 \sigma$ (Table 2).

\subsection{Quantitative dietary reconstruction}

The Bayesian mixing model FRUITS (Fernandes et al., 2014) was applied. It was implemented using:

* five food groups $\left(\mathrm{C}_{3}\right.$ plants/including tuber, legumes and fruits; $\mathrm{C}_{4}$ plants; meat; milk and fish).

* three dietary proxies ( $\delta^{13}$ Capatite, $\delta^{13}$ Ccollagen and $\delta^{15}$ Ncollagen).

$*$ three food fractions (bulk, proteins and energy $=$ lipids + carbohydrates), whose amount was expressed as the percentage of the total calories of each food group, calculated using data from FAOSTAT for Mali in 1961 and converting proteins and lipids from $g$ to $\mathrm{kcal}$ knowing that proteins contain $4 \mathrm{kcal} / \mathrm{g}$ and lipids, $9 \mathrm{kcal} / \mathrm{g}$ (see Fernandes et al., 2014). Results were rounded up and provided for cereals: $10 \%$ proteins $/ 10 \%$ lipids $/ 80 \%$ carbohydrates; meat: $40 \%$ proteins $/ 60 \%$ lipids; milk: $20 \%$ proteins $/ 55 \%$ lipids $/ 25 \%$ carbohydrates; for fish, $65 \%$ proteins and 35\% lipids were used as average values (Fernandes et al., 2015). An uncertainty of 5\% was assigned to each macronutrient.
* Dogon and pre-Dogon bones population average values: $\delta^{13}$ Capatite, $\delta^{13}$ Ccollagen; $\delta^{15}$ Ncollagen (cf. Table 1).

* diet-to-tissue offsets and weight contribution for each dietary proxy, as determined and reviewed by Fernandes et al. (2012), and issued from lab controlled experiments i.e., $\delta^{13} \mathrm{C}$ diet-to-apatite offset $=10.1 \pm 0.04 \%$ (routed $100 \%$ from bulk $\delta^{13} \mathrm{C}$ diet); $\delta^{13} \mathrm{C}$ diet-to-collagen offset $=4.8 \pm 0.5 \%$ (routed $74 \%$ from proteins and $26 \%$ from carbohydrates) and $\delta^{15} \mathrm{~N}$ diet-to-collagen offset $=3.6 \pm 1.2 \%$ (routed $100 \%$ from the dietary proteins).

* isotopic composition of each food fraction, calculated as follows, according to known isotopic offsets between proteins, lipids and carbohydrates relevant to each food group:

1) $\delta^{13} \mathrm{C}$ protein and $\delta^{13} \mathrm{C}$ energy ( $\sim 90 \%$ carbohydrates) of $\mathrm{C}_{3}$ and $\mathrm{C}_{4}$ plants, were based on measured plant $\delta^{13} \mathrm{C}$ (Table 1) and calculated using $\delta^{13}$ Cplant [bulk-proteins] $=2 \%$ and $\delta^{13}$ Cplant [bulk-carbohydrates] $=-0.5 \%$ (Tieszen, 1991). Measured plants $\delta^{15} \mathrm{~N}$ values were directly used;

2) $\delta^{13} \mathrm{C}$ of meat proteins and lipids were estimated based on bone collagen $\delta^{13} \mathrm{C}$ values of the pre-Dogon Bos sp. (Table 1) and $\delta^{13} \mathrm{C}$ meat [protein-collagen] $=-2.5 \%$ and $\delta^{13} \mathrm{C}$ meat [proteinlipid] $=6 \%$ (Tieszen, 1991; Tieszen and Fagre, 1993). Meat bulk $\delta^{13} \mathrm{C}$ value was calculated considering $\delta^{13} \mathrm{C}$ of meat proteins and lipids and their weight contribution (FAOSTAT Mali 1961). Meat protein $\delta^{15} \mathrm{~N}$ was calculated according to $\delta^{15} \mathrm{~N}$ meat [protein-collagen] $=2 \%$ (Fernandes et al., 2015) based on measured bone collagen $\delta^{15} \mathrm{~N}$ of the pre-Dogon Bos sp.;

3) Milk protein, lipid and carbohydrate $\delta^{13} \mathrm{C}$ values were estimated based on pre-Dogon Bos sp. bone collagen $\delta^{13} \mathrm{C}$ values and calculated using offsets between $\delta^{13} \mathrm{C}$ [collagen-diet $]=4.8 \%$ (Fernandes et al., 2012), $\delta^{13} \mathrm{C}[$ casein-diet $]=1.1 \%$ o (Schneider et al., 2015), [diet-bulk] $=0.4 \%$ (Schneider et al., 2015), [dietlipid $]=2.2 \%$ and $[$ diet-carbohydrates $]=-0.7 \%$ (Schneider et al., 2015). Milk $\delta^{13} \mathrm{C}$ energy was calculated according to weight contribution of lipids (53\%) and carbohydrates (27\%) (FAOSTAT, Mali 1961) and their respective isotopic composition. Milk $\delta^{15} \mathrm{~N}$ value was estimated based on measured herbivore bone pre-Dogon collagen $\delta^{15} \mathrm{~N}$ and isotopic offset $\delta^{15} \mathrm{~N}$ [milkcollagen $=-2 \%$ (Reynard and Tuross, 2015); 4) Finally, $\delta^{13} \mathrm{C}$ 
Table 1

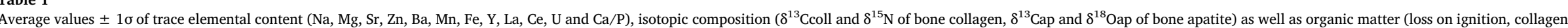

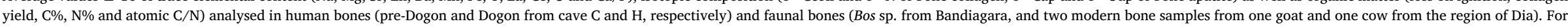

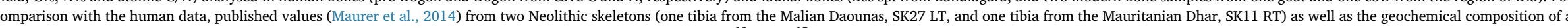

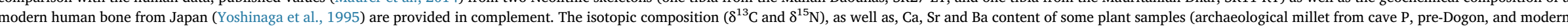
millet from Senegal and fonio from Mali) is also given. Additionally, $\delta^{13} \mathrm{C}$ and $\delta^{15} \mathrm{~N}$ values of modern millet and sorghum analysed with ${ }^{*}$ ) and without any solvent pre-treatment are provided.

Data in italics were below the quantification limit for trace elements, and corrected from the industrial effect by adding $1.5 \%$ (Indermuhle et al., 1999) for $\delta^{13} \mathrm{C}$ measured in modern fauna and plant samples.

\begin{tabular}{|c|c|c|c|c|c|c|c|c|c|c|c|c|}
\hline & & \multicolumn{4}{|l|}{ Humans } & \multicolumn{3}{|l|}{ Fauna } & \multicolumn{4}{|l|}{ Plants } \\
\hline & & Pre-Dogon & Dogon & Neolithic & Fresh & Pre-Dogon & Fresh & Fresh & Pre-Dogon & Fresh & Fresh & Fresh \\
\hline & & $11^{\text {th }}-16^{\text {th }}$ & $17^{\text {th }}-20^{\text {th }}$ & & Bone & Bos $\mathrm{p}$. & Goat & Cow & Millet & Millet and sorghum & Millet and fonio & Rice \\
\hline & & Bandiagara & Bandiagara & Daounas/Dhar Nema & & Bandiagara & DIA & DIA & Bandiagara & DIA/unknown location/*unknown location lipids extracted & Unknown location & DIA \\
\hline & & Mali & Mali & Mali/Mauritania & Japan & Mali & Mali & Mali & Mali & Mali & Mali/Senegal & Mali \\
\hline \multicolumn{13}{|l|}{ Trace elements } \\
\hline $\mathrm{Ca} / \mathrm{P}$ & & $2.22 \pm 0.04$ & $2.24 \pm 0.05$ & $2.31 / 2.23$ & 2.07 & $2.15 \pm 0.04$ & 2.10 & 2.14 & (Ca) 9.76 & & (Ca) 0.88 & \\
\hline $\mathrm{Na}$ & $\%$ & $0.74 \pm 0.03$ & $0.78 \pm 0.03$ & $0.27 / 0.21$ & 0.8 & & & & & & & \\
\hline $\mathrm{Mg}$ & $\%$ & $0.46 \pm 0.02$ & $0.48 \pm 0.02$ & $0.09 / 0.07$ & 0.44 & & & & & & & \\
\hline $\mathrm{Sr}$ & $\mu \mathrm{g} \cdot \mathrm{g}^{-1}$ & $207 \pm 49$ & $215 \pm 51$ & $1198 / 319$ & 124 & $353 \pm 13$ & 927 & 652 & 634 & & $67 \pm 23$ & \\
\hline $\mathrm{Zn}$ & $\mu g \cdot g^{-1}$ & $126 \pm 16$ & $114 \pm 13$ & & 229 & & & & & & & \\
\hline $\mathrm{Ba}$ & $\mu g \cdot g^{-1}$ & $6 \pm 2$ & $4 \pm 1$ & $5714 / 111$ & 2 & $398 \pm 75$ & 3076 & 1161 & 1055 & & $179 \pm 177$ & \\
\hline $\mathrm{Mn}$ & $\mu g \cdot g^{-1}$ & $1.7 \pm 3.95$ & $0.7 \pm 0.31$ & $33 / 64$ & $<0.2$ & & & & & & & \\
\hline $\mathrm{Fe}$ & $\mu \mathrm{g} \cdot \mathrm{g}^{-1}$ & $27 \pm 13$ & $30 \pm 7$ & $482 / 253$ & 109 & & & & & & & \\
\hline $\mathrm{Y}$ & $\mu \mathrm{g} \cdot \mathrm{g}^{-1}$ & $0.08 \pm 0.05$ & $0.06 \pm 0.02$ & & $<0.04$ & & & & & & & \\
\hline $\mathrm{La}$ & $\mu g \cdot g^{-1}$ & $0.08 \pm 0.05$ & $0.06 \pm 0.02$ & $0.23 / 0.55$ & $<0.04$ & & & & & & & \\
\hline $\mathrm{Ce}$ & $\mu g \cdot g^{-1}$ & $0.19 \pm 0.12$ & $0.11 \pm 0.04$ & $0.27 / 0.79$ & & & & & & & & \\
\hline $\mathrm{U}$ & $\mu g \cdot g^{-1}$ & $0.01 \pm 0.00$ & $0.01 \pm 0.00$ & $11 / 0.7$ & $<0.006$ & & & & & & & \\
\hline \multicolumn{13}{|l|}{ Isotopes } \\
\hline$\delta^{13} \mathrm{Ccoll}$ & $\%$ & $-11.4 \pm 0.6$ & $-10.9 \pm 0.8$ & & & $-7.4 \pm 0.4$ & -18.9 & -7.5 & $-8.8 \pm 0.0$ & $-9.5 \pm 0.8 /-9.5 \pm 0.3 / *-9.6 \pm 0.5$ & $-8.6 \pm 0.2$ & -25.6 \\
\hline$\delta^{15} \mathrm{~N}$ & $\%$ & $8.0 \pm 0.4$ & $7.7 \pm 1.1$ & & & $7.7 \pm 1.0$ & 10.3 & 6.6 & $13.7 \pm 0.8$ & $6.6 \pm 2.0 / 6.2 \pm 0.1 / * 5.6 \pm 2.5$ & $5.1 \pm 0.3$ & 4.6 \\
\hline$\delta^{13} \mathrm{Cap}$ & $\%$ & $-5.4 \pm 0.6$ & $-4.6 \pm 0.6$ & & & $-0.1 \pm 0.5$ & -11.3 & -0.9 & & & & \\
\hline$\delta^{18}$ Oap & $\%$ & $-0.6 \pm 0.9$ & $-2.1 \pm 0.8$ & & & $5.5 \pm 0.5$ & 11.1 & -0.2 & & & & \\
\hline \multicolumn{13}{|l|}{ Organic matter } \\
\hline Ignition loss & $\%$ & $36 \pm 2$ & $37 \pm 1$ & $5 / 4$ & & $39 \pm 3$ & 32 & 35 & & & & \\
\hline Collagen yield & $\%$ & $11 \pm 3$ & $16 \pm 6$ & & & $5 \pm 1$ & 23 & 24 & & & & \\
\hline C & $\%$ & $42 \pm 1$ & $43 \pm 1$ & & & $41 \pm 1$ & 43 & 43 & & & & \\
\hline $\mathrm{N}$ & $\%$ & $14 \pm 1$ & $15 \pm 0$ & & & $14 \pm 0$ & 14 & 15 & & & & \\
\hline $\mathrm{C} / \mathrm{N}$ atomic & & $3.4 \pm 0$ & $3.3 \pm 0$ & & & $3.3 \pm 0$ & 3.5 & 3.3 & & & & \\
\hline
\end{tabular}


Table 2

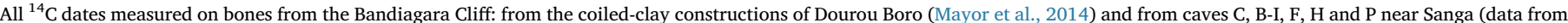

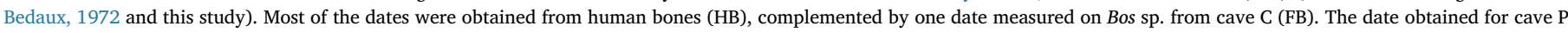

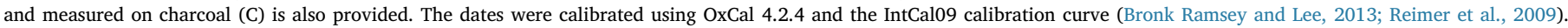
Calibrated intervals are given at $2 \sigma$.

\begin{tabular}{|c|c|c|c|c|c|c|}
\hline Location & Structure & Sample \# & AMS \# & 14C age BP & Cal $2 \sigma \mathrm{AD}$ & Reference \\
\hline Dourou-Boro & Coiled clay tomb & HB T1 & ETH-33578 & $1355 \pm 35$ & $614-768$ & Mayor et al., 2014 \\
\hline Dourou-Boro & Coiled clay tomb & HB T3 & ETH-33579 & $1350 \pm 40$ & $614-771$ & Mayor et al., 2014 \\
\hline Dourou-Boro & Coiled clay tomb & HB T2 & ETH-33587 & $1295 \pm 40$ & $651-853$ & Mayor et al., 2014 \\
\hline Sanga & Cave C & $\mathrm{HB}$ & GX-0470 & $895 \pm 95$ & $979-1281$ & Bedaux, 1972 \\
\hline Sanga & Cave C & $\mathrm{HB}$ & GX-0752 & $855 \pm 55$ & $1040-1267$ & Bedaux, 1972 \\
\hline Sanga & Cave C & HB & GX-0469 & $780 \pm 95$ & $1033-1391$ & Bedaux, 1972 \\
\hline Sanga & Cave $\mathrm{C}$ & FB & SacA34283 & $650 \pm 30$ & $1280-1395$ & This study \\
\hline Sanga & Cave C & $\mathrm{HB}$ & SacA34278 & $580 \pm 30$ & $1300-1419$ & This study \\
\hline Sanga & Cave C & $\mathrm{HB}$ & SacA34285 & $550 \pm 30$ & $1310-1435$ & This study \\
\hline Sanga & Cave C & $\mathrm{HB}$ & SacA34279 & $405 \pm 30$ & $1433-1624$ & This study \\
\hline Sanga & Cave B-I & $\mathrm{HB}$ & GX-0232 & $655 \pm 125$ & $1043-1473$ & Bedaux, 1972 \\
\hline Sanga & Cave F & $\mathrm{HB}$ & GX-0795 & $390 \pm 85$ & $1400-1795$ & Bedaux, 1972 \\
\hline Sanga & Cave F & $\mathrm{HB}$ & GX- 0753 & $200 \pm 90$ & $1497-1954$ & Bedaux, 1972 \\
\hline Sanga & Cave $\mathrm{H}$ & $\mathrm{HB}$ & SacA34277 & $155 \pm 30$ & $1666-1953$ & This study \\
\hline Sanga & Cave $\mathrm{H}$ & $\mathrm{HB}$ & SacA34276 & $115 \pm 30$ & 1680-1939 & This study \\
\hline Sanga & Cave P & $\mathrm{C}$ & GX-0233 & $680 \pm 95$ & $1164-1433$ & Bedaux, 1972 \\
\hline
\end{tabular}

and $\delta^{15} \mathrm{~N}$ of fish bone collagen from the Niger River (Perga et al., 2005) were used to estimate fish meat, energy and bulk $\delta^{13} \mathrm{C}$, according to determined isotopic offsets between $\delta^{13} \mathrm{C}[$ meatcollagen] $=-1 \%$ and $\delta^{13} \mathrm{C}$ [lipids-collagen $]=-7 \%$ as well as weight contributions of the different food fractions $(65 \%$ protein and 35\% lipids, Fernandes et al., 2015).

* also, prior information was added and based on: 1) the protein part of the diet varying from 10 to $15 \%$ of the total calorie intake, which corresponds to dietary protein intake in modern west African populations (ReSAKSS, 2011); and 2) a second prior, consisting in a minimal amount of $50 \%$ of C4 plant intake, as in rural Mali today (FAO, 1999).

\section{Results and discussion}

\subsection{Radiocarbon dating}

The ${ }^{14} \mathrm{C}$ ages are reported in detail in Table 2 in conjunction with all previously published available dates obtained from human bones at Bandiagara for comparison (Bedaux, 1972; Mayor et al., 2014) as well as one date obtained from charcoal in Cave P (Bedaux, 1972).

The ${ }^{14} \mathrm{C}$ ages measured in this study on human bones from Cave $\mathrm{C}$ (including the date provided by a sample of Bos sp.) range from $650 \pm 30 \mathrm{BP}(1280-1395 \mathrm{cal} \mathrm{AD})$ to $550 \pm 30 \mathrm{BP}(1310-1435 \mathrm{cal}$ $\mathrm{AD})$, with one bone displaying a date of $405 \pm 30 \mathrm{BP}(1433-1624 \mathrm{cal}$ $\mathrm{AD})$. These individuals are therefore more recent than those dated by Bedaux (1972) ranging from $895 \pm 95$ BP (979-1281 cal AD) to $780 \pm 95$ BP (1033-1391 cal AD). According to these new radiocarbon dates, the pre-Dogon buried in Cave $\mathrm{C}$ might have been in contact with the first Dogon, whose arrival to the Cliff is estimated to date from the 13th-15th cent. $\mathrm{AD}$ (Mayor et al., 2005). The ${ }^{14} \mathrm{C}$ measured on two human bones from Cave $\mathrm{H}$ provided very recent dates, of $155 \pm 30$ BP (1666-1953 cal AD) and $115 \pm 30$ BP (1680-1939 cal $\mathrm{AD}$ ) in agreement with oral traditions transmitted by the modern Dogon (Bedaux, 1972).

\subsection{Preservation of the Dogon and pre-Dogon bones}

In arid environments, bone collagen rarely survives (Maurer et al., 2014; Saliège et al., 1995). However, the skeletons buried in the caves of the Bandiagara Cliff seem to have been exceptionally well preserved. All human pre-Dogon and Dogon samples analysed in this study yield average values of $42.4 \pm 0.9 \%$ of C, $14.7 \pm 0.6 \%$ of $\mathrm{N}, 12.7 \pm 5.1 \%$ of collagen and a $\mathrm{C} / \mathrm{N}$ ratio averaging $3.4 \pm 0.1$ (Table 1 ), data that is compliant with established criteria routinely used for assessing the preservation state of bone collagen (DeNiro, 1985; Van Klinken, 1999). Collagen of the archaeological faunal herbivore bones from Bandiagara yield similar average values of $\% \mathrm{C}(41 \%), \% \mathrm{~N}(14 \%)$ and $\mathrm{C} / \mathrm{N}(3.3)$ to that of the human bones, as well as the fresh goat and cow bone from Dia, with however, a lower collagen yield $(4.9 \pm 0.6 \%)$. An explanation other than analytical bias cannot be given as \% weight loss of preDogon faunal bones during the ashing procedure averages that of the human bones arguing therefore for roughly similar bone organic matter content. In all cases, the collagen yield of the archaeological faunal bones is sufficient for assessing its quality.

The XRD diffractograms of the Dogon and pre-Dogon femora are also fairly similar to that of fresh bone (Fig. 5). They display poorlycrystalline carbonate hydroxylapatite (Person et al., 1996) and contrast well with higher crystallinity usually observed in archaeological bone samples (Person et al., 1996) and especially in arid environments (Maurer et al., 2014). In addition, no diagenetic mineral has been detected on the diffractograms which purely consist of carbonate hydroxylapatite.

Likewise, the histological patterns of the pre-Dogon and Dogon femora clearly contrast with those observed on Neolithic human bones buried in the Mauritanian Dhar and in the Inner Niger Delta (Maurer et al., 2014). The Bandiagara bones show very well preserved Haversian system, high collagen birefringence, absence of traces due to microbial attack, absence of microcracks as well as no mineral inclusion in bone porosity (Fig. 4).

Above all, modifications of the geochemical composition of the Bandiagara bones seem excluded as bone $\mathrm{Ca} / \mathrm{P}$ (average $=2.23 \pm$ 0.04 ), $\mathrm{Na}$ (average $=0.76 \pm 0.04 \%$ ), $\mathrm{Mg}$ (average $=0.47 \pm 0.02 \%$ ), Mn (average $=1.2 \pm 2.8 \mu \mathrm{g} \cdot \mathrm{g}^{-1}$ ), $\mathrm{Y}\left(\right.$ average $=0.07 \pm 0.04 \mu \mathrm{g} \cdot \mathrm{g}^{-1}$ ), La (average $=0.07 \pm 0.04 \mu \mathrm{g} \cdot \mathrm{g}^{-1}$ ) and $\mathrm{U}$ (average $=0.013 \pm$ $0.004 \mu \mathrm{g} \cdot \mathrm{g}^{-1}$ ) content, especially, are nearly identical to those measured in modern Japanese ribs (Yoshinaga et al., 1995, Table 1).

Very local environmental conditions involving stable temperature and humidity have obviously prevailed in these caves over centuries. Protected from alteration, the bones buried there yield organic, mineralogical, histological and geochemical features that are almost indistinguishable to those of fresh bones. Their overall preservation state therefore allows for a palaeodietary study in an almost perfect context, which ensures that biogenic geochemical composition is still archived in the bones. 


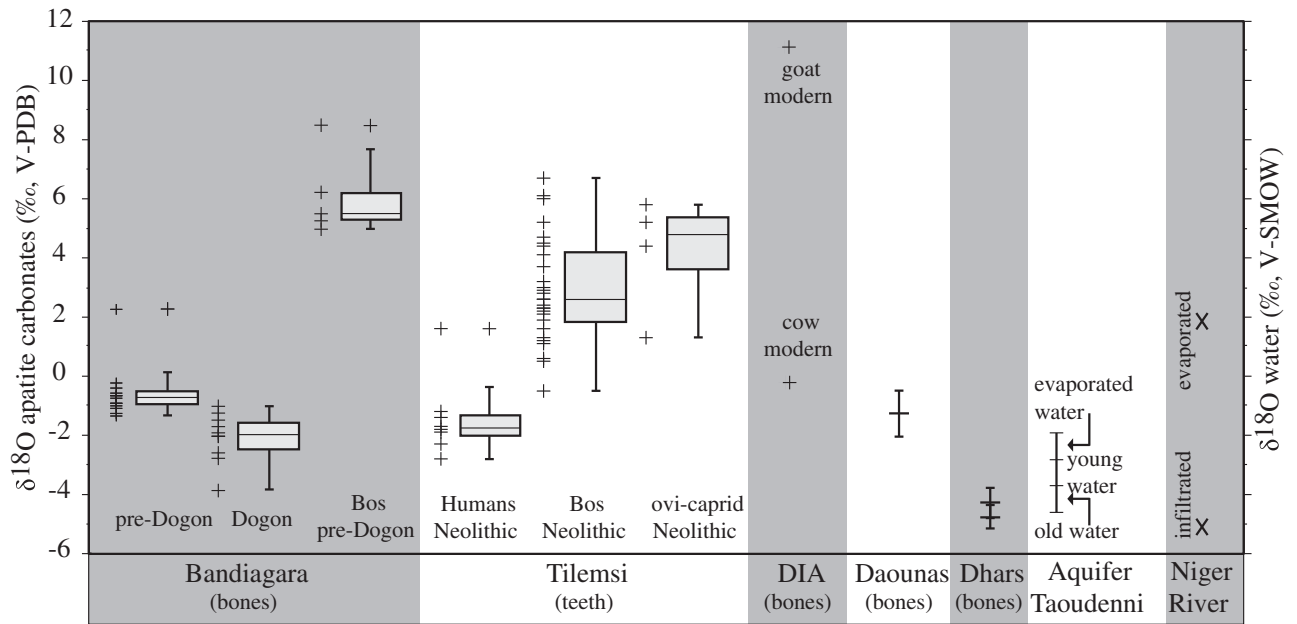

Fig. 6. Bone $\delta^{18} \mathrm{O}$ values recorded in skeletons from Bandiagara: in human populations Tellem (cave $\mathrm{C}$ ) and Dogon (cave $\mathrm{H}$ ), and in bones of Bos sp. (cave $C$ and $P$, Tellem). For comparison, published $\delta^{18} \mathrm{O}$ values recorded in skeletons from the Niger geo-ecosystem (the Tilemsi valley, DIA and the Daounas, Fig. 1) and from the Mauritanian Dhar are displayed on the graph with: teeth $\delta^{18} \mathrm{O}$ values of Neolithic humans and herbivores (Bos sp. and ovi-caprids) from Tilemsi (Finucane et al. 2008); $\delta^{18} \mathrm{O}$ values of Neolithic human bones from the Daounas and the Dhar (Maurer et al., 2014); and bone $\delta^{18} \mathrm{O}$ ratios measured in modern goat and cow mandibles (this study). Published $\delta^{18} \mathrm{O}$ values measured in the Taoudenni aquifer (Dakoure, 2003) and the Niger River water (Gourcy et al., 2000) are also presented. $\delta^{18} \mathrm{O}$ values recorded in the skeletons are reported as $\%$ V-PDB, while water $\delta^{18} \mathrm{O}$ values were calibrated relative to $\mathrm{V}-\mathrm{SMOW}$.

\subsection{Settlement of Dogon and pre-Dogon populations within the Bandiagara} escarpment

Oxygen isotope values archived in the bones of the pre-Dogon and of the Dogon relate to the isotopic composition of their drinking water (Bryant et al., 1994; D'Angela and Longinelli, 1990; Delgado Huertas et al., 1995; Longinelli, 1984; Luz and Kolodny, 1985) itself derived from geo-environmental factors (Dansgaard, 1964).

Pre-Dogon and Dogon human bones yield $\delta^{18} \mathrm{O}$ values averaging $-1.3 \pm 1.1 \%$ and ranging from $-3.9 \%$ to $2.2 \%$. These values are in agreement with published $\delta^{18} \mathrm{O}$ measured in archaeological human populations from the Niger River geoecosystem (Fig. 6), i.e. teeth of individuals dated from the Neolithic buried in the Tilemsi Valley (Finucane et al., 2008) and bones of one Neolithic skeleton excavated in the Malian Daounas (Maurer et al., 2014).

Yet, Bandiagara escarpment is a very different geoecosystem from that of the Niger River. At Bandiagara, hydrological resources are composed of the groundwater stored in the Cambro-Ordovician sandstones (the Taoudenni aquifer) and of the precipitations infiltrating this karstic system (Dakoure, 2003). Hydrology of the Niger River geoecosystem, however, is controlled by interactions between the deep aquifer, heavy rains and evaporation (Gourcy et al., 2000). Although hydrological processes of both geoecosystems are complex, they do not yield a specific and distinguishable $\delta^{18} \mathrm{O}$ signature (Fig. 6): $\delta^{18} \mathrm{O}$ of the Niger River overlaps that of the Taoudenni aquifer, at least in modern times. Therefore, $\delta^{18} \mathrm{O}$ does not seem to be a good proxy for tracing regional mobility in Mali.

Nevertheless, at a local scale, that of the Bandiagara environment, subtle but significant differences exist between bone oxygen isotopic values of the Dogon and the pre-Dogon (average $\delta^{18} \mathrm{O}$ values: $-2.1 \pm 0.8 \%$ and $-0.6 \pm 0.9 \%$, respectively; Mann-Whitney $\mathrm{U}=6, \mathrm{n} 1=10, \mathrm{n} 2=13, \mathrm{P}=0.0002$, two-tailed). This could result from contrasting environmental conditions during the pre-Dogon and the Dogon phases, i.e. arid vs. humid, involving changes in $\delta^{18} \mathrm{O}$ of the drinking water supply. However, this is difficult to evaluate considering the instability of the climate through the 11th-19th cent. AD (Mayor et al., 2005). If such difference happens to relate to climate change, higher bone $\delta^{18} \mathrm{O}$ values of the pre-Dogon compared to those of the Dogon, would suggest drier climate somewhere within the 11th-16th cent. $\mathrm{AD}$ than it was in the 17 th-20th cent. $\mathrm{AD}$. Bone $\delta^{18} \mathrm{O}$ values yielded by these skeletons may also evidence the utilisation of distinct drinking water sources by both populations, which may argue for different settlement location within the Cliff. The high number of individuals buried in Cave $C$ together with higher bone $\delta^{18} \mathrm{O}$ ratios of the pre-Dogon may indicate that this population settled onto the Plateau as opposed to the Dogon, who probably occupied the Cliff.

In all cases, pre-Dogon and Dogon populations both lived in the same geoecosystem as assessed by their very low bone Ba amounts $\left(<10 \mu \mathrm{g} \cdot \mathrm{g}^{-1}\right.$, Table 1$)$. This is typical in desert environments (Burton and Price, 1990) where Ba is not bioavailable as it combines with soil sulphates (Perel'man, 1977).

Interestingly, bones of herbivores dated from the pre-Dogon period yield much higher Ba amounts $\left(\sim 400 \mu \mathrm{g} \cdot \mathrm{g}^{-1}\right.$, Table 1$)$. They have also recorded higher $\delta^{18} \mathrm{O}$ values than the human pre-Dogon bones (average $\delta^{18} \mathrm{O}$ values: $5.5 \pm 0.5 \%$ and $-0.6 \pm 0.9 \%$, respectively; MannWhitney $\mathrm{U}=52, \mathrm{n} 1=4, \mathrm{n} 2=13, \mathrm{P}=0.003$, two-tailed, Fig. 6 ). This pattern was also observed at Karkarinchinkat (Tilemsi Valley) between herbivores (bovines and ovi-caprines) and human teeth $\delta^{18} \mathrm{O}$ values (Finucane et al., 2008) (Fig. 6).

Different physiologies, drinking behavior and diet (Kohn et al., 1996) between humans and herbivores may lead to differences in their bones $\delta^{18} \mathrm{O}$ values. Specific relation between apatite $\delta^{18} \mathrm{O}$ values and drinking water $\delta^{18} \mathrm{O}$ ratios were established by D'Angela and Longinelli (1990) and Chenery et al. (2012), respectively:

for cattle: $\delta^{18} \mathrm{O}_{\text {bonePO}}(\mathrm{V}-\mathrm{SMOW})=1.01 \times \delta^{18} \mathrm{O}_{\text {water }(\mathrm{V}-\mathrm{SMOW})}+24.90$

for humans: $\delta^{18} \mathrm{O}_{\text {water(V-SMOW) }}=1.590 \times \delta^{18} \mathrm{O}_{\text {enamelCO }_{3}}(\mathrm{~V}-\mathrm{SMOW})$ $-48.634$

Applying these equations, using a spacing $\delta^{18} \mathrm{O}_{\mathrm{CO} 3-\mathrm{PO} 4}$ of around 9\%o (Chenery et al., 2012; Iacumin et al., 1996) and converting $\delta^{18} \mathrm{O}$ values from V-SMOW to V-PDB (Coplen, 1988), a difference of at least $2 \%$ is expected between cattle bone $\delta^{18} \mathrm{O}$ values and human teeth $\delta^{18} \mathrm{O}$ ratios who would drink water with similar isotopic composition arbitrarily chosen as $-2 \%$.

A larger difference between cattle bone $\delta^{18} \mathrm{O}$ values and human bone $\delta^{18} \mathrm{O}$ ratios might be expected, considering a fractionation between teeth and bone $\delta^{18} \mathrm{O}$ values (Warinner and Tuross, 2009; Webb et al., 2014).

Although it is difficult to rely solely on these conversion equations as they yield multiple uncertainties, the discrepancies in bone $\delta^{18} \mathrm{O}$ between pre-Dogon Bos sp. and humans values $(\sim 6 \%)$, together with bone Ba content seem to point out a non-local origin of the pre-Dogon bovines. Likely present in the cave as goods for the dead, these cattle might have lived further away in the Plain, which would be compatible with modern habits in the Dogon Country, where most of the cattle is brought to the Plain near the Burkina border during the rainy season and to the inner Niger Delta during the dry season (Van Dijk and De Bruijn, 2004). However, the very high Ba content of the modern sheep/ goat $\left(3076 \mu \mathrm{g} \cdot \mathrm{g}^{-1}\right)$ and cow bones $\left(1161 \mu \mathrm{g} \cdot \mathrm{g}^{-1}\right)$ from Dia (Table 1) might exclude any movement of the pre-Dogon Bos sp. to the Niger Delta, unless their bone Ba content results from averaging extreme values (very high in the Delta versus very low around the Cliff).

In conclusion, Ba and eventually $\delta^{18} \mathrm{O}$ values recorded in animals and humans from Bandiagara only evidence mobility of the cattle while the mobility of the human population was restricted to the environment 


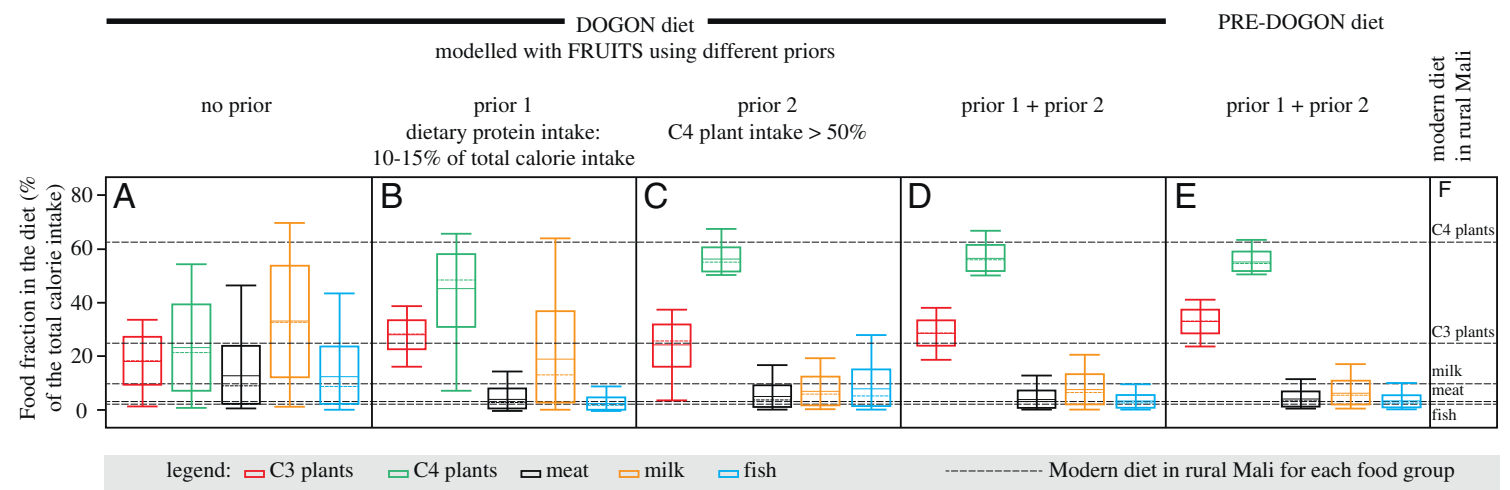

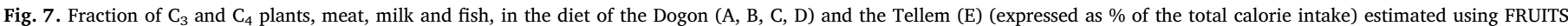

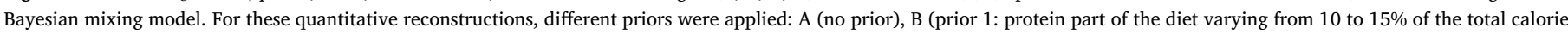

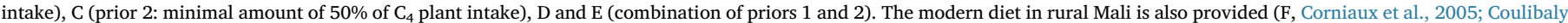
and Kébé, 2003; FAO, 1999).

of the Cliff. The geochemical composition of the bones analysed in this study therefore do not show any external demographic influence. However, any conclusion related to socio-dynamic interactions between the inhabitants of the Cliff and larger areas will be inferred only after the analysis of skeletons buried in various caves, and especially, bone samples recently discovered from the older coiled clay structure, in which glass beads from Asia were found (Mayor et al., 2014).

\subsection{Diet of the Dogon and the pre-Dogon populations at Bandiagara}

The Bayesian mixing model FRUITS (Fernandes et al., 2014) was applied for quantitative reconstruction of the dietary habits of the Dogon buried in Bandiagara Cave H (17th-20th cent. AD), using the geochemical composition of their bones (Table 1), i.e., $\delta^{13}$ Capatite $(-4.6 \pm 0.6 \%), \quad \delta^{13}$ Ccollagen $\quad(-10.9 \pm 0.8 \% 0) \quad$ and $\quad \delta^{15} \mathrm{~N}$ $(7.7 \pm 1.1 \% 0)$. The model was built upon the isotopic composition of the fractions (bulk, protein and energy) of each food source $\left(\mathrm{C}_{3}\right.$ plants; $\mathrm{C}_{4}$ plants; meat; milk and fish). This was deduced from isotopic offsets between proteins, lipids and carbohydrates relevant to each food group (cf. 4.4) and from measured stable isotopic composition of: $\mathrm{C}_{3}$ plants (modern Malian cultivated rice, with average $\delta^{13} \mathrm{C}:-25.6 \% 0$ and $\delta^{15} \mathrm{~N}$ : 4.6\%), $\mathrm{C}_{4}$ plants (archaeological/modern Malian millet, modern Malian sorghum and fonio, with average $\delta^{13} \mathrm{C}$ : $-9.2 \%$ and $\delta^{15} \mathrm{~N}$ : $5.8 \%$ ), and faunal herbivore bone collagen from Bandiagara Caves $\mathrm{C}$ and $\mathrm{P}$ (with average $\delta^{13}$ Capatite: $-0.1 \pm 0.5 \%$, $\delta^{13}$ Ccollagen: $-7.4 \pm 0.4 \%$ and $\delta^{15} \mathrm{~N}$ : $7.7 \pm 1.0 \%$ ). Here, it is worth mentioning that the solvent pre-treatment of the plant samples did not affect plant $\delta^{13} \mathrm{C}$ values, while plant $\delta^{15} \mathrm{~N}$ values were variable whether they were pre-treated or not (see Table 1), with however, roughly similar averages (difference of $0.6 \%$ ).

Two priors were considered independently and simultaneously: an amount of protein intake in the diet ranging from $10 \%$ to $15 \%$, as well as a minimal amount of $50 \%$ of $\mathrm{C}_{4}$ plant consumption. Both priors were based on data issued from modern surveys conducted in Mali/West Africa (Coulibaly and Kébé, 2003; FAO, 1999; ReSAKSS, 2011). Results obtained from the model vary substantially according to whether or not prior information was added. When no prior was applied, diet of the Dogon population did not display any clear pattern for the consumption of $\mathrm{C}_{4}$ and $\mathrm{C}_{3}$ plants, milk, meat and fish, which were not well constrained and oscillated between roughly 10 and $30 \%$ in average. A dietary trend emerged with the addition of the protein intake as a prior information, showing $\mathrm{C}_{3}, \mathrm{C}_{4}$ plants and milk as the main dietary food sources, with lower contribution of meat and fish. However, variability of $\mathrm{C}_{4}$ and milk intake was very high (with a standard deviation of around $15 \%$ ). Using a prior based on a minimal contribution of $50 \%$ of $\mathrm{C}_{4}$ to the diet displayed fairly similar dietary habits of the Dogon studied to that of modern Malian/West African populations, with heavy reliance $(\sim 80 \%)$ on plants and ancillary importance $(\sim 20 \%)$ of animal proteins.

When both priors were combined, variability in $\mathrm{C}_{3}$ plants and fish intake was reduced and the dietary pattern refined, leaving almost no doubt that the Dogon buried in Cave $\mathrm{H}$ had about the same dietary habits at least in terms of consumption, to modern populations in rural Mali. Slight differences were observed though, with lower consumption of $\mathrm{C}_{4}(57 \pm 5 \%)$ and milk ( $8 \pm 5 \%$ ), and higher consumption of $\mathrm{C}_{3}$ (29 $\pm 5 \%$ ), in average. Consumption of meat and fish was lower than $4 \%$. These discrepancies may arise from several assumptions that were made to run the Bayesian model FRUITS. Indeed, most of the isotopic data used was estimated from stable isotope ratios measured in cereals and Bos sp. collagen (to estimate isotopic composition of meat and milk used for the model, Table 1), but: 1) isotopic offsets may vary due to physiology and diet; 2) species other than Bos sp. might have provided meat and milk; 3) $C_{3}$ plants group aggregates $C_{3}$ cereals, tubers, legumes and fruits although they may yield very different protein amounts; 4) plant $\delta^{15} \mathrm{~N}$ is highly variable in nature (Szpak, 2014), but the model was based only on a few sets of data from cereals while tuber, legumes and fruits constitute $\sim 11 \%$ of the diet in rural Mali today (FAO, 1999); 5) plant $\delta^{15} \mathrm{~N}$ was impacted by solvent pre-treatment; 6) modern cereals provided plant $\delta^{15} \mathrm{~N}$ values which may have been slightly different from that of the plants ingested by Dogon and preDogon populations according to the fertilization techniques employed (Fraser et al., 2011) and 7) fish isotopic data was estimated according to values provided by Perga et al. (2005), from South Mali, while fish isotopic composition may be highly variable depending on the environment.

Yet, despite lots of imperfections in the implementation of this model, the results issued using both, the amount of dietary proteins, as well as $\mathrm{C}_{4}$ plants intake, as priors, seem consistent with present day consumption of $\mathrm{C}_{3}$ and $\mathrm{C}_{4}$ plants, meat, milk and fish in rural Mali (Fig. 7). The geochemical composition of Dogon bones buried in Cave $\mathrm{H}$ therefore shows that dietary habits seem to have been fairly similar over the past 300 years in rural Mali. It is difficult however, to firmly assess that dietary habits at Bandiagara specifically, were exactly the same 300 years ago as today, as dietary patterns in the Dogon country are known only from a qualitative point of view (Dieterlen and CalameGriaule, 1960). Nevertheless, it is possible to compare the diet of the Dogon dated from the 17th to 20th to that of the pre-Dogon dated from the 11th to 16th cent. AD. who lived in the same environment of the Bandiagara Cliff, and whose ways of life and dietary practices are not known.

FRUITS was therefore applied, using the same combination of prior information, to the pre-Dogon buried in Cave C, whose bones registered slightly different geochemical composition: $\delta^{13}$ Capatite $(-5.4 \pm 0.6 \%$ ), $\delta^{13}$ Ccollagen $(-11.4 \pm 0.6 \%)$ and $\delta^{15} \mathrm{~N}(8.0 \pm 0.4 \% 0)$. Overall similar 
dietary pattern to that of the Dogon was generated by the model (Fig. 7). Interestingly, only women were buried in the Dogon Cave $\mathrm{H}$ (Bedaux, 1972), while both sexes were found in the pre-Dogon Cave C. Although sex determination was based on the skulls buried in the caves and could not be done for the long bones analysed in this study, these results may suggest that women and men could have had relatively similar dietary habits from the 11th cent. AD to today in rural Mali, at least in term of amount ingested.

A slight difference, however, between the diet of the pre-Dogon and that of the Dogon, was found in the ingestion of $\mathrm{C}_{3}$ plants, $4 \%$ higher for the pre-Dogon than for the Dogon, while the amount of $\mathrm{C}_{4}$, meat, milk and fish was broadly similar (the difference did not exceed $2 \%$ ).

Although some roots and tubers, such as manioc and sweet potatoes were introduced to Africa during the 16th cent. AD (Toury et al., 1967), the skeletons buried in pre-Dogon Cave $C$ dated from the 11th to 16th cent. $\mathrm{AD}$ seem to have had a somewhat stronger reliance on $\mathrm{C}_{3}$ plants that may reflect a higher consumption of rice, fruits and other wild plant species, whose remains have been found in Sadia (Seno-Gondo Plain, 8th-13th; Huysecom et al., 2012) and in pre-Dogon cave P (Bedaux, 1972).

Another interesting observation was the higher variability in $\delta^{15} \mathrm{~N}$ displayed by the Dogon bones buried in Cave H (Table 1). As only females were buried there, this may arise from pregnancy effect (Nitsch et al., 2010) or suggest more varied food sources.

This dietary reconstruction was entirely based on bone isotopic values, while bone trace element content might also provide useful dietary information. However, the dietary proxy commonly used for reconstructing diet, bone $\mathrm{Sr} / \mathrm{Ca}$ ratio, does not allow us to go further in the dietary reconstruction. This is because data from the archaeological millet (Cave P) and Bos sp. samples required for establishing a baseline to which compares the human data do not seem appropriate. It is actually impossible that the very high calcium content $(>9 \%)$ measured in the millet sample reflects the chemical composition of millet alone, the Ca content of which should average $<1 \%$ (National Research Council, 1996). Although the samples have been rinsed in demineralised water prior to analysis, we suspect bat guano, a Ca-rich compound which was covering the plant sample in Cave P (Bedaux, 1972), to be very likely responsible for these unforeseen results. This would also explain the very high $\delta^{15} \mathrm{~N}$ value measured in this sample of millet $\left(13.7 \%\right.$ ) resembling $\delta^{15} \mathrm{~N}$ measured in the feather of modern insectivorous birds (Oppel et al., 2011).

Likewise, as bone Ba content and $\delta^{18} \mathrm{O}$ values of Bos sp. pre-Dogon show a non-local origin of these herbivores, at least to the Cliff, $\mathrm{Sr} / \mathrm{Ca}$ yielded by their bone cannot be directly used for comparison with bone $\mathrm{Sr} / \mathrm{Ca}$ of the human population.

However, although quantitative reconstruction of the dietary practices of the pre-Dogon and Dogon populations cannot be provided using bone $\mathrm{Sr} / \mathrm{Ca}$ and $\mathrm{Ba} / \mathrm{Ca}$, comparable $\mathrm{Sr}$ and $\mathrm{Ba}$ amounts yielded by the pre-Dogon and the Dogon (with Sr average of $207 \pm 49 \mu \mathrm{g} \cdot \mathrm{g}^{-1}$ and $215 \pm 51 \mu \mathrm{g} \cdot \mathrm{g}^{-1}$, and $\mathrm{Ba}$ average of $6 \pm 2 \mu \mathrm{g} \cdot \mathrm{g}^{-1}$ and $4 \pm 1 \mu \mathrm{g} \cdot \mathrm{g}^{-1}$, respectively), also argue for very similar diets.

Finally, bone $\mathrm{Zn}$ levels (100 $\mu \mathrm{g} \cdot \mathrm{g}^{-1}$ in average), of both Dogon and pre-Dogon, might reflect a low meat intake (Bodorikova et al., 2010; Scarabino et al., 2006). Regarding their low bone Fe content (30 $\mu \mathrm{g} \cdot \mathrm{g}^{-1}$ in average), this could connect to the detection of cribra orbitalia (Knip, 1971). However, no straightforward relationship between bone $\mathrm{Zn}$ and Fe concentrations and the diet has been validated so far (Dolphin and Goodman, 2009; Ezzo, 1994; Glen-Haduch et al., 1997; Mcilvaine, 2015; Walker et al., 2009).

Therefore, although trace elements cannot be directly used here for a quantitative dietary reconstruction, they provide infomation about very similar diets of the pre-Dogon and Dogon populations studied. Furthermore, as collagen almost never survives in arid areas (Maurer et al., 2014; Saliège et al., 1995), the trace elemental composition of the pre-Dogon and Dogon populations of Bandiagara will provide archaeological reference for further dietary and mobility studies conducted in that region. Additionally, this data will also constitute a database for non-industrial area of West Africa, useful for medical and environmental purposes.

\section{Summary and conclusions}

The bones buried in the sepulchral caves of Bandiagara are exceptionally well preserved. Thus, their pristine geochemical composition faithfully reflects the way of life of pre-Dogon and Dogon populations from the 10 th to 16 th cent. $\mathrm{AD}$ and 17 th to 20 th cent. $\mathrm{AD}$, respectively. They unveil that the oldest population buried in the Cave C, the so-called "Tellem", very likely lived on the Bandiagara Plateau while the most recent Dogon population occupied the Cliff. Both populations had a restricted mobility within a similar geological environment, that of the Cliff. In contrast, non-local origin was detected in the bones of pre-Dogon herbivores (cattle) accompanying the dead in the caves, whose movements were probably dictated by seasons and followed Fulani herders.

Although subtle dietary differences have been detected in the bones of the Dogon and the pre-Dogon, relying more specifically on $\mathrm{C}_{3}$ (rice, wild and collected plants), there is no real discordance in the dietary habits of the pre-Dogon and Dogon populations which seem to have prevailed over centuries. While the pre-Dogon buried in Cave C might have seen the arrival of the first Dogon to the Cliff, the samples analysed argue for a homogeneous population in terms of dietary habits (but not in terms of morphology) and do not show any presence of allochthonous individuals. If this was the case, they very likely adopted local dietary habits.

Results acquired from individuals buried in these two specific caves therefore do not show any external demographic influence in connection with the adjacent Empires but rather point to "strong local cultural identity" (Mayor et al., 2014), at least from a geochemical point of view.

Nevertheless, for far-reaching conclusions about the lifestyle and the socio-economic system of the Dogon and their predecessors, further dietary studies integrating other caves should be conducted now that the biogeochemical baseline is set-up.

\section{Acknowledgments}

This work was funded by the ACI 67053 . We wish to thank the Institut de Recherche pour le Développement (IRD, Bondy Paris) for the use of their facilities, as well as the National Museum of Natural History (MNHN, Paris). Many thanks are also due to Nathalie Labourdette, Veronique Vaury and Marylene Person (Paris VI), Thierry Pilorge (IRD Bondy) and Olivier Tomberet (MNHN, Paris) for their technical assistance. Many thanks are also due to Corina Knipper (Curt Engelhorn Center, Mannheim, Germany) and Ricardo Fernandes (University of Kiel, Germany and University of Cambridge, UK) for their availability and fruitful discussions. Finally, we want to thank two anonymous reviewers for improving the manuscript, as well as Rebecca MacRoberts, for proofreading the manuscript.

\section{References}

Alt, K., Knipper, C., Peters, D., Müller, W., Maurer, A.-F., Kollig, I., Nicklisch, N., Müller, C., Karimnia, S., Brandt, G., Roth, C., Rosner, M., Mende, B., Schöne, B., Vida, T., von Freeden, U., 2014. Lombards on the move? An integrative study of the migration period cemetery at Szólád, Hungary. PLoS One. http://dx.doi.org/10.1371/journal. pone.0110793.

Arnay-de-la-Rosa, M., Gamez-Mendoza, A., Navarro-Mederos, J.F., Hernandez-Marrero, J.C., Fregel, R., Yanes, Y., Galindo-Martin, L., Romanek, C.S., Gonzalez-Reimers, E., 2009. Dietary patterns during the early prehispanic settlement in La Gomera (Canary Islands). J. Archaeol. Sci. 36, 1972-1981.

Arnay-de-la-Rosa, M., González-Reimers, E., Yanes, Y., Romanek, C.S., Noakes, J.E. Galindo-Martín, L., 2011. Paleonutritional and paleodietary survey on prehistoric humans from Las Cañadas del Teide (Tenerife, Canary Islands) based on chemical and histological analysis of bone. J. Archaeol. Sci. 38, 884-895.

Balter, V., 2001. Les rapports $\mathrm{Sr} / \mathrm{Ca}$ et $\mathrm{Ba} / \mathrm{Ca}$ dans les phosphates biogéniques. In: 
Applications paléo-écologiques et paléo-anthropologiques. Université de Bordeaux et de Paris VI, Thèse.

Balter, V., Bocherens, H., Person, A., Renard, M., Labourdette, N., Vandermeersch, B., 2002. Ecological and physiological variability of $\mathrm{Sr} / \mathrm{Ca}$ and $\mathrm{Ba} / \mathrm{Ca}$ in mammals of West European mid-Wurmian foodwebs. Palaeogeogr. Palaeoclimatol. Palaeoecol. 186, 127-143.

Balter, V., Braga, J., Telouk, P., Thackeray, F., 2012. Evidence for dietary change but not landscape use in South African early hominins. Nature 489, 558-560.

Balter, V., Person, A., Labourdette, N., Drucker, D., Renard, M., Vandermeersch, B., 2001. Were Neandertalians essentially carnivores? Sr and Ba preliminary results of the mammalian palaeobiocoenosis of Saint-Césaire. Comptes Rendus de l'Académie des Sciences IIA 332, 59-65.

Banga, P., 2004. Les Dogon et leur environnement naturel. In: Bedaux, R., Van der Waals, J.D. (Eds.), Regards sur les Dogon du Mali. Rijksmuseum voor Volkenkunde. Leyde et Snoeck, Gand, pp. 15-22.

Bedaux, R., 1972. Tellem, reconnaissance archéologique d'une culture de l'Ouest africain au Moyen Age: recherches architectoniques. Journal de la Société des Africanistes 42, 103-185.

Bedaux, R.M.A., 1986. Recherches ethno-archéologiques sur la poterie des Dogon (Mali). In: Fokkens, H., Banga, P., Bierma, M. (Eds.), Op zoek naar mens en materiële cultuur. Feestbundel aangeboden aan J.D. van der Waals. R.U. Groningen, pp. 117-146.

Bedaux, R., 1988. Tellem and Dogon material culture. Afr. Arts 21 (38-45), 91.

Bedaux, R., 2004. Les premiers Dogon dans la region de Sangha. In: Bedaux, R., Van der Waals, J.D. (Eds.), Regards sur les Dogon du Mali. Rijksmuseum voor Volkenkunde. Leyde et Snoeck, Gand, pp. 37-39.

Bedaux, R., van der Waals, J.D., 2004. Regards sur les Dogon du Mali. In: Rijksmuseum voor Volkenkunde. Leyde et Editions Snoek, Gand.

Bocherens, H., Fizet, M., Mariotti, A., Lange-Badre, B., Vandermeersch, B., Borel, J.P., Bellon, G., 1991. Isotopic biogeochemistry $\left({ }^{13} \mathrm{C},{ }^{15} \mathrm{~N}\right)$ of fossil vertebrate collagen: application to the study of a past food web including Neanderthal man. J. Hum. Evol. 20, 481-492.

Bodorikova, S., Katina, S., Kováčová, V., Kvetánová, I., Urminský, J., Kubová, J., Domonkošová, Tibenská K., 2010. Analysis of trace elements in the teeth of individuals from the former crypt in St. Catherine monastery in Dechtice (district Trnava, Slovakia). Scr. Med. 83, 49-58.

Brasseur, G., Le Moal, G., 1963. Cartes ethno-demographiques de l'Afrique occidentale. In: Feuilles 3-4 Nord. IFAN, Dakar (30p).

Bronk Ramsey, C., Lee, S., 2013. Recent and planned developments of the program OxCal. Radiocarbon 55 (2-3), 720-730.

Bryant, J.D., Luz, B., Froelich, P.N., 1994. Oxygen isotopic composition of fossil horse tooth phosphate as a record of continental paleoclimate. Palaeogeogr. Palaeoclimatol. Palaeoecol. 107, 303-316.

Burton, J.H., Price, T.D., 1990. The ratio of barium to strontium as a paleodietary indicator of consumption of marine resources. J. Archaeol. Sci. 17, 547-557.

Burton, J.H., Price, T.D., Middleton, W.D., 1999. Correlation of bone Ba/Ca and Sr/Ca due to biological purification of calcium. J. Archaeol. Sci. 26, 609-616.

Chenery, C.A., Pashley, V., Lamb, A.L., Sloane, H.J., Evans, J.A., 2012. The oxygen isotope relationship between the phosphate and structural carbonate fractions of human bioapatite. Rapid Commun. Mass Spectrom. 26, 309-319.

Child, A.M., 1995. Toward an understanding of the microbial decomposition of archaeological bone in the burial environment. J. Archaeol. Sci. 22, 165-174.

Collins, M.J., Nielsen-Marsh, C.M., Hiller, J., Smith, C.I., Roberts, J.P., 2002. The survival of organic matter in bone: a review. Archaeometry 44, 383-394.

Coplen, T.B., 1988. Normalization of oxygen and hydrogen isotope data. Chem. Geol. Isot. Geosci. 72, 293.

Corniaux, C., Niafo, Y., Poccard-Chapuis, R., Coulibaly, D., 2005. Consommation de lait et de produits laitiers dans les ménages de Segou (Mali). Projet FSP Bov 9-2. Recherche de modes d'exploitation économique et durable des troupeaux bovins laitiers dans les periurbains du Mali.

Coulibaly, B.S., Kébé, D., 2003. Sécurité alimentaire au Mali. The Roles of Agriculture International Conference, Rome, Italy.

Dakoure, D., 2003. Etude hydrogéologique et géochimique de la bordure sud-est du bassin sédimentaire de Taoudeni (Burkina Faso - Mali). Essai de modelisation. Thèse de l'Université Paris VI.

D'Angela, D., Longinelli, A., 1990. Oxygen isotopes in living mammal's bone phosphate: further results. Chem. Geol. 86, 75-82.

Dansgaard, W., 1964. Stable isotopes in precipitation. Tellus 16, 436-468.

Daveau, S., 1959. Recherches morphologiques sur la région de Bandiagara. IFAN, Dakar (120 p. Mémoire IFAN 56).

Degryse, P., Muchez, P., De Cupere, B., Van Neer, W., Waelkens, M., 2004. Statistical treatment of trace element data from modern and ancient animal bone: Evaluation of Roman and Byzantine environmental pollution. Anal. Lett. 37, 2819-2834.

Delgado Huertas, A., Iacumin, P., Stenni, B., Chillón, B.S., Longinelli, A., 1995. Oxygen isotope variations of phosphate in mammalian bone and tooth enamel. Geochim. Cosmochim. Acta 59, 4299-4305.

DeNiro, M.J., 1985. Postmortem preservation and alteration of in vivo bone collagen isotope ratios in relation to palaeodietary reconstruction. Nature $317,806-809$.

DeNiro, M.J., Epstein, S., 1978. Influence of diet on the distribution of carbon isotopes in animals. Geochim. Cosmochim. Acta 42, 495-506.

DeNiro, M.J., Epstein, S., 1981. Influence of diet on the distribution of nitrogen isotopes in animals. Geochim. Cosmochim. Acta 45, 341-351.

Desplagnes, L., 1907. Le Plateau Central Nigérien. Larose, Paris (504 p).

Dieterlen, G., 1941. Les âmes des Dogons. In: Travaux et Mémoires de l'Institut d'Ethnologie 40. Institut d'Ethnologie, Paris.

Dieterlen, G., Calame-Griaule, G., 1960. L'alimentation Dogon. Cahiers d'Etudes Africaines 1 (3), 46-89.
Dolphin, A.E., Goodman, A.H., 2009. Maternal diets, nutritional status, and zinc in contemporary Mexican infants' teeth: implications for reconstructing paleodiets. Am. J. Phys. Anthropol. 140, 399-409.

Doquet, A., 2005. Une nature dogon? L'occultation de l'environnement naturel dans la patrimonialisation du pays dogon. In: Cormier-Salem, M.-C., Juhé-Beaulaton, D., Boutrais, J., Roussel, B. (Eds.), Patrimoines naturels au Sud: territoires, identités et stratégies locales. IRD, Paris (2005).

Ehleringer, J.R., 1989. Carbon isotope ratios and physiological processes in aridland plants. In: Rundel, P.W., Ehleringer, J.R., Nagy, K.A. (Eds.), Stable Isotopes in Ecological Research. Springer, New York, pp. 41-54.

Elias, R.W., Hirao, Y., Patterson, C.C., 1982. The circumvention of the natural biopurification of calcium along nutrient pathways by atmospheric inputs of industrial lead. Geochim. Cosmochim. Acta 46, 2561-2580.

Ezzo, J.A., 1994. Zinc as a paleodietary indicator: an issue of theoretical validity in bonechemistry analysis. Am. Antiq. 59, 606-621.

FAO, 1999. Aperçus nutritionnels par Pays, Mali. Food and Agriculture Organization of the United Nations, Rome, Italy.

Fernandes, R., Grootes, P., Nadeau, M.-J., Nehlich, O., 2015. Quantitative diet reconstruction of a Neolithic population using a Bayesian mixing model (FRUITS): the case study of Ostorf (Germany). Am. J. Phys. Anthropol. 158, 325-340.

Fernandes, R., Millard, A.R., Brabec, M., Nadeau, M.-J., Grootes, P., 2014. Food reconstruction using isotopic transferred signals (FRUITS): a Bayesian model for diet reconstruction. PLoS 9, e87436.

Fernandes, R., Nadeau, M.-J., Grootes, P.M., 2012. Macronutrient-based model or dietary carbon routing in bone collagen and bioapatite. Archaeol. Anthropol. Sci. 4, 291-301.

Finucane, B., Manning, K., Toure, M., 2008. Late stone age subsistence in the Tilemsi Valley, Mali: stable isotope analysis of human and animal remains from the site of Karkarichinkat Nord (KN05) and Karkarichinkat Sud (KS05). J. Anthropol. Archaeol. 27, 82-92.

Fraser, R.A., Bogaard, A., Heaton, T., Charles, M., Jones, G., Christensen, B.T., Halstead, P., Merbach, I., Poulton, P.R., Sparkes, D., Styring, A.K., 2011. Manuring and stable nitrogen isotope ratios in cereals and pulses: towards a new archaeobotanical approach to the inference of land use and dietary practices. J. Archaeol. Sci. 38 2790-2804.

Gallais, J., 1965. Le paysan Dogon (République du Mali). Cahiers d'Outre-mer 18, 123-143.

Gallay, A., Huysecom, E., Mayor, A., 1995. Archéologie, histoire et traditions orales: trois clés pour découvrir le passé dogon. In: Homberger, L. (Ed.), Die Kunst der Dogon. Museum Rietberg, Zürich, pp. 19-43.

Glen-Haduch, E., Szostek, K., Glab, H., 1997. Cribra orbitalia and trace element content in human teeth from Neolithic and Early Bronze Age graves in Southern Poland. Am. J. Phys. Anthropol. 103, 201-207.

Gourcy, L., Aranyossy, J.-F., Olivry, J.-C., Zuppi, G.M., 2000. Evolution spatio-temporelle des teneurs isotopiques $(\delta 2 \mathrm{H}-\delta 18 \mathrm{O})$ des eaux de la cuvette lacustre du fleuve Niger (Mali). Comptes Rendus de l'Académie des Sciences, Paris, Earth and Planetary Science 331, 701-707.

Griaule, M., 1932. La mission Dakar-Djibouti, rapport général (mai 1931-mai 1932). Journal de la Société des Africanistes 2, 113-122.

Griaule, M., 1938. Masques Dogons. In: Travaux et Mémoires de l'Institut d'Ethnologie 33. Institut d'Ethnologie, Paris.

Griaule, M., Dieterlen, G., 1965. Le renard pâle. Tome 1: Le mythe cosmogonique. Fasc. 1 : La création du Monde. Travaux et Mémoires de l'Institut d'Ethnologie. Institut d'Ethnologie, Paris.

Hedges, R.E.M., Millard, A.R., Pike, A.W.G., 1995. Measurements and relationships of diagenetic alteration of bone from three archaeological sites. J. Archaeol. Sci. 22, 201-209.

Huizinga, J., 1968. New physical anthropological evidence bearing on the relationships between Dogon, Kurumba and the extinct West African Tellem populations. Proc. Kon. Ned. Akad. Wetensch., Ser. C 71, 16-30.

Huysecom, E., 2002. Palaeoenvironment and human population in West Africa: an international research project in Mali. Antiquity 76, 335-336.

Huysecom, E., Ozainne, S., Mayor, A., Jeanbourquin, C., Loukou, S., Canetti, M., Ballouche, A., Cantin, N., Cisse, L., Eichhorn, B., Kahlheber, S., Rasse, M., Sanogo, K., 2012. Fouilles en Pays dogon et reconnaissance archéologique au Sénégal oriental: la 14ème année de recherches du programme. In: Peuplement humain et paléoenvironnement en Afrique de l'Ouest.

Iacumin, P., Bocherens, H., Mariotti, A., Longinelli, A., 1996. Oxygen isotope analyses of co-existing carbonate and phosphate in biogenic apatite: a way to monitor diagenetic alteration of bone phosphate? Earth Planet. Sci. Lett. 142, 1-6.

Indermuhle, A., Stocker, T., Joos, F., Fischer, H., Smith, H., Wahlen, M., Deck, B. Mastroianni, D., Tschumi, J., Blunier, T., Meyer, R., Stauffer, B., 1999. Holocene carbon-cycle dynamics based on $\mathrm{CO}_{2}$ trapped in ice at Taylor Dome, Antartica. Nature 398, 121-126.

Jans, M.M.E., Nielsen-March, C.M., Smith, C.I., Collins, M.J., Kars, H., 2004. Characterisation of microbial attack on archaeological bone. J. Archaeol. Sci. 31, 87-95.

Knip, A., 1971. The frequencies of non-metrical variants in Tellem and Nokara skulls from the Mali Republic. Proc. Kon. Ned. Akad. Wetensch., Ser. C 74, 422-443.

Kohn, M.J., Schoeninger, M.J., Valley, J.W., 1996. Herbivore tooth oxygen isotope compositions: effects of diet and physiology. Geochim. Cosmochim. Acta 60, 3889-3896.

Loftus, E., Roberts, P., Lee-Thorp, J.A., 2016. An isotopic generation: four decades of stable isotope analysis in African archaeology. In: Azania: Arachaeological Research in Africa. 2016, 51. pp. 88-114.

Longin, R., 1971. New method of collagen extraction for radiocarbon dating. Nature 230, 241-242. 
Longinelli, A., 1984. Oxygen isotopes in mammal bone phosphate: a new tool for paleohydrological and paleoclimatological research? Geochim. Cosmochim. Acta 48, 385-390.

Lösch, S., Moghaddam, N., Grossschmidt, K., Risser, D.U., Kanz, F., 2014. Stable isotope and trace element studies on gladiators and contemporary Romans from Ephesus (Turkey, 2nd and 3rd Ct. AD) - implications for differences in diet. PLoS ONE 9, e110489.

Luz, B., Kolodny, Y., 1985. Oxygen isotope variations in phosphate of biogenic apatites. IV. Mammal teeth and bones. Earth Planet. Sci. Lett. 75, 29-36.

Maurer, A.-F., 2008. Les signaux biogéochimiques enregistrés dans les ossements humains de populations anciennes constituent-ils un document archéologique fiable? These de l'Universite Paris VI.

Maurer, A.-F., Gerard, M., Person, A., Barrientos, I., del Carmen Ruiz, P., Darras, V., Durlet, C., Zeitoun, V., Renard, M., Faugère, B., 2011. Intra-skeletal variability in trace elemental content of Precolumbian Chupicuaro human bones: the record of post-mortem alteration and a tool for palaeodietary reconstruction. J. Archaeol. Sci. $38,1784-1797$.

Maurer, A.-F., Person, A., Tütken, T., Amblard-Pison, S., Segalen, L., 2014. Bone diagenesis in arid environments: an intra-skeletal approach. Palaeogeogr. Palaeoclimatol. Palaeoecol. 416, 17-29.

Mayor, A., Huysecom, E., Gallay, A., Rasse, M., Ballouche, A., 2005. Population dynamics and paleoclimate over the past 3000 years in the Dogon country, Mali. J. Anthropol. Archaeol. 24, 25-61.

Mayor, A., Huysecom, E., Ozainne, S., Magnavita, S., 2014. Early social complexity in the Dogon Country (Mali) as evidenced by new chronology of funerary practices. J. Anthropol. Archaeol. 34, 17-41.

Mays, S., 2003. Bone strontium: calcium ratios and duration of breastfeeding in a mediaeval skeletal population. J. Archaeol. Sci. 30, 731-741.

Mcilvaine, B.K., 2015. Implications of reappraising the iron deficiency anemia hypothesis. Int. J. Osteoarchaeol. 25, 997-1000.

National Research Council, 1996. Lost Crops of Africa. Vol. 1 National Academy Press, Washington D.C.

Nitsch, K.E., Humphrey, L.T., Hedges, R.E.M., 2010. The effect of parity status on $\delta^{15} \mathrm{~N}$ : looking for the "pregnancy effect" in 19th century London. J. Archaeol. Sci. 37, 3191-3199.

O'Leary, M.H., 1981. Carbon isotope fractionation in plants. Phytochemistry 20, 553-567.

Oppel, S., Pain, D.J., Lindsell, J.A., Lachmann, L., Diop, I., Tegetmeyer, C., Donald, P.F., Anderson, G., Bowden, C.G.R., Tanneberger, F., Flade, M., 2011. High variation reduces the value of feather stable isotope ratios in identifying new wintering areas for aquatic warblers Acrocephalus paludicola in West Africa. J. Avian Biol. 42 (342), 354.

Ozainne, S., 2013. Un Néolithique ouest-africain. Cadre chrono-culturel, économique et environnemental de l'Holocène récent en pays dogon (Mali). J. Afr. Archeol. Monog. Ser. 8 ((Humain Population \& Palaeoenvironement in West Africa; 3). Africa Magna Verlag, Frankfurt am Main).

Palau Marti, M., 1957. Les Dogon. Monographies ethnologiques africaines. Presses Universitaires de France, Paris (122 p).

Pate, F.D., Hutton, J.T., Norrish, K., 1989. Ionic exchange between soil solution and bone: toward a predictive model. Appl. Geochem. 4, 303-316.

Perel'man, A.I., 1977. Geochemistry of Elements in the Supergene Zone. Israel Program for Scientific Translations, Jerusalem.

Perga, M.-E., Arfi, R., Gerdeaux, D., 2005. Seasonal variations in fish $\delta^{13} \mathrm{C}$ and $\delta^{15} \mathrm{~N}$ in two west African reservoirs, Selingue and Manantali (Mali): modifications of trophic links in relation to water level. Isot. Environ. Health Stud. 41, 109-123.

Person, A., Bocherens, H., Mariotti, A., Renard, M., 1996. Diagenetic evolution and experimental heating of bone phosphate. Palaeogeogr. Palaeoclimatol. Palaeoecol. 126, $135-149$.

Person, A., Amblard-Pison, S., Jousse, H., Vallette, T., Albaret, C., Raimbault, M., Maurer, A.-F., Suire, J., 2012. Influence de l'environnement sur la gestion des ressources au Néolithique dans la zone refuge du Dhar Néma (Mauritanie sud-orientale). J. Afr. Archaeol. 10, 133-164.

Pfretzschner, H.-U., Tütken, T., 2011. Rolling bones — taphonomy of jurassic dinosaur bones inferred from diagenetic microcracks and mineral infillings. Palaeogeogr. Palaeoclimatol. Palaeoecol. 310, 117-123.

Piepenbrink, H., Schutkowski, H., 1987. Decomposition of skeletal remains in desert dry soil a roentgenological study. Hum. Evol. 2, 481-491.

Rasmussen, K.L., Skytte, L., Pilekær, C., Lauritsen, A., Boldsen, J.L., Leth, P.M., Thomsen, P.O., 2013. The distribution of mercury and other trace elements in the bones of two human individuals from medieval Denmark — the chemical life history hypothesis. Herit. Sci. 1, 10.

Reimer, P.J., Baillie, M.G.L., Bard, E., Bayliss, A., Beck, J.W., Blackwell, P.G., Bronk Ramsey, C., Buck, C.E., Burr, G.S., Edwards, R.L., Friedrich, M., Grootes, P.M., Guilderson, T.P., Hajdas, I., Heaton, T.J., Hogg, A.G., Hughen, K.A., Kaiser, K.F., Kromer, B., McCormac, F.G., Manning, S.W., Reimer, R.W., Richards, D.A., Southon, J.R., Talamo, S., Turney, C.S.M., van der Plicht, J., Weyhenmeyer, C.E., 2009.
IntCal09 and Marine09 radiocarbon age calibration curves, 0-50,000 years cal BP. Radiocarbon 51 (4), 1111-1150.

ReSAKSS, 2011. Étude de la consommation alimentaire en Afrique de l'Ouest. (Rapport de synthèse. Sl: ReSAKSS).

Reynard, L.M., Tuross, N., 2015. The known, the unknown and the unknowable: weaning times from archaeological bones using nitrogen isotope ratios. J. Archaeol. Sci. 53, 618-625.

Salesse, K., Dufour, E., Lebon, M., Wurster, C., Castex, D., Bruzek, J., Zazzo, A., 2014. Variability of bone preservation in a confined environment: the case of the catacomb of Sts Peter and Marcellinus (Rome, Italy). Palaeogeogr. Palaeoclimatol. Palaeoecol. 416, 43-54.

Saliège, J.F., Person, A., Paris, F., 1995. Preservation of ${ }^{13} \mathrm{C} /{ }^{12} \mathrm{C}$ original ratio and ${ }^{14} \mathrm{C}$ dating of the mineral fraction of human bones from Saharan tombs, Niger. J. Archaeol. Sci. 22, 301-312.

Scarabino, C., Lubritto, C., Proto, A., Rubino, M., Fiengo, G., Marzaioli, F., Passariello, I., Busiello, G., Fortunato, A., Alfano, D., Sabbarese, C., Rogalla, D., De Cesare, N., D'Onofrio, A., Terrasi, F., 2006. Paleodiet characterization of an Eturian population of Pontecagnano (Italy) by Isotope Ratio Mass Spectrometry (IRMS) and Atomic Absorption Spectrometry (AAS). Isot. Environ. Health Stud. 42, 151-158.

Scheeres, M., Knipper, C., Hauschild, M., Schönfelder, M., Siebel, W., Vitali, D., Pare, C., Alt, K.W., 2013. Evidence for "Celtic migrations"? Strontium isotope analysis at the early La Tène (LT B) cemeteries of Nebringen (Germany) and Monte Bibele (Italy). J. Archaeol. Sci. 40, 3614-3625.

Schneider, S., Auerswald, K., Bellof, G., Schnyder, H., 2015. ${ }^{13} \mathrm{C}$ discrimination between diet, faeces, milk and milk components. Isot. Environ. Health Stud. 51, 33-45.

Shafer, M.M., Siker, M., Overdier, J.T., Ramsl, P.C., Teschler-Nicola, M., Farrell, P.M., 2008. Enhanced methods for assessment of the trace element composition of Iron Age bone. Sci. Total Environ. 401, 144-161.

Skytte, L., Rasmussen, K.L., 2013. Sampling strategy and analysis of trace element concentrations by inductively coupled plasma mass spectrometry on medieval human bones - the concept of chemical life history. Rapid Commun. Mass Spectrom. 2013 (27), 1591-1599.

Sponheimer, M., de Ruiter, D., Lee-Thorp, J., Späth, A., 2005. Sr/Ca and early hominin diets revisited: new data from modern and fossil tooth enamel. J. Hum. Evol. 48, 147-156.

Stipisic, A., Versic-Bratincevic, M., Knezovic, Z., Sutlovic, D., 2014. Metal content in medieval skeletal remains from Southern Croatia. J. Archaeol. Sci. 46, 393-400.

Szpak, P., 2014. Complexities of nitrogen isotope biogeochemistry in plant-soil systems: implications for the study of ancient agricultural and animal management practices. Front. Plant Sci. 5, 1-19.

Tieszen, L.L., 1991. Natural variations in the carbon isotope values of plants: implications for archaeology, ecology, and paleoecology. J. Archaeol. Sci. 18, 227-248.

Tieszen, L.L., Fagre, T., 1993. Effect of diet quality and composition on the isotopic composition of respiratory $\mathrm{CO} 2$, bone collagen, bio-apatite, and soft tissues. In: Lambert, J.B., Norr, L. (Eds.), Prehistoric Human Bone. Archaeology at the Molecular Level. Springer, New York, pp. 121-155.

Toury, J., Giorgi, R., Favier, J.C., Savina, J.F., 1967. Aliments de l'ouest africain, tables de composition. Annales de la Nutrition et de l'Alimentation 21, 73-127.

Van Beek, W.E.A., 1991. Dogon restudied. A field evaluation of the work of Marcel Griaule. Curr. Anthropol. 32 (2), 139-158.

Van Dijk, H., De Bruijn, M., 2004. Répartition des terres et stratégies agricoles au Pays Dogon. In: Bedaux, R., Van der Waals, J.D. (Eds.), Regards sur les Dogon du Mali. Rijksmuseum voor Volkenkunde Leyde et Snoeck, Gand, pp. 23-29.

Van Klinken, G.J., 1999. Bone collagen quality indicators for palaeodietary and radiocarbon measurements. J. Archaeol. Sci. 26, 687-695.

Walker, P.L., Bathurst, R.R., Richman, R., Gjerdrum, T., Andrushko, V., 2009. The causes of porotic hyperostosis and cribra orbitalia: a reappraisal of the iron-deficiency-anemia hypothesis. Am. J. Phys. Anthropol. 139, 109-125.

Warinner, C., Tuross, N., 2009. Alkaline cooking and stable isotope tissue-diet spacing in swine: archaeological implications. J. Archaeol. Sci. 36, 1690-1697.

Webb, E.C., White, C.D., Longstaffe, F.J., 2014. Investigating inherent differences in isotopic composition between human bone and enamel bioapatite: implications for reconstructing residential histories. J. Archaeol. Sci. 50, 97-107.

White, C.D., 2005. Gendered food behaviour among the Maya: time, place, status and ritual. J. Soc. Archaeol. 5, 356-382.

Yoshinaga, Y., Suzuki, T., Morita, M., Hayakawa, M., 1995. Trace elements in ribs of elderly people and elemental variation in the presence of chronic diseases. Sci. Total Environ. 162, 239-252.

Zeitoun, V., Gatto, E., Rougier, H., Schmidt, A., Saliege, J.-F., Keita, D., Bedaux, R., 2005 Les sépultures. In: Bedaux, R., Polet, J., Sanogo, K., Schmidt, A. (Eds.), Recherches archéologiques à Dia dans le Delta intérieur du Niger (Mali): bilan des saisons de fouilles 1998-2003. Mededelingen van het Rijksmuseum voor Volkenkunde Leiden 33. CNWS Publications, Leiden, pp. 143-176.

http://faostat.fao.org/site/368/DesktopDefault.aspx?PageID = 368\#ancor. 